\title{
New Archaeological Investigations at the M. S. Roberts Site (41HE8) in the Caddo Creek Valley in Henderson County, Texas
}

Timothy K. Perttula

Heritage Research Center, Stephen F. Austin State University

Arlo McKee

Texas Historical Commission

Mark Walters

Heritage Research Center, Stephen F. Austin State University

Bo Nelson

Heritage Research Center, Stephen F. Austin State University

Follow this and additional works at: https://scholarworks.sfasu.edu/ita

Part of the American Material Culture Commons, Archaeological Anthropology Commons, Environmental Studies Commons, Other American Studies Commons, Other Arts and Humanities Commons, Other History of Art, Architecture, and Archaeology Commons, and the United States History Commons

Tell us how this article helped you.

This Article is brought to you for free and open access by the Center for Regional Heritage Research at SFA ScholarWorks. It has been accepted for inclusion in Index of Texas Archaeology: Open Access Gray Literature from the Lone Star State by an authorized editor of SFA ScholarWorks. For more information, please contact cdsscholarworks@sfasu.edu. 
New Archaeological Investigations at the M. S. Roberts Site (41HE8) in the Caddo Creek Valley in Henderson County, Texas

\section{Creative Commons License}

\section{(c) (1) \&}

This work is licensed under a Creative Commons Attribution-NonCommercial 4.0 International License 


\title{
New Archaeological Investigations at the M. S. Roberts Site (41HE8) in the Caddo Creek Valley in Henderson County, Texas
}

\author{
Timothy K. Perttula, Arlo McKee, Mark Walters, and Bo Nelson
}

\section{Introduction}

In this article, we discuss new archaeological investigations at the M. S. Roberts site (41HE8), likely a $14^{\text {th }}$ to early $15^{\text {th }}$ century A.D. Caddo period mound center along Caddo Creek in the upper Neches River basin in Henderson County in East Texas (Figure 1). With the permission and cooperation of the landowners, we completed an aerial survey of the site to produce a detailed topographic map as well as assess the plan and profile of the mound and its associated borrow pit, and we also excavated a number of shovel tests around the mound to locate habitation deposits. Finally, a few auger holes were excavated to determine the internal structure of the M. S. Roberts site mound.

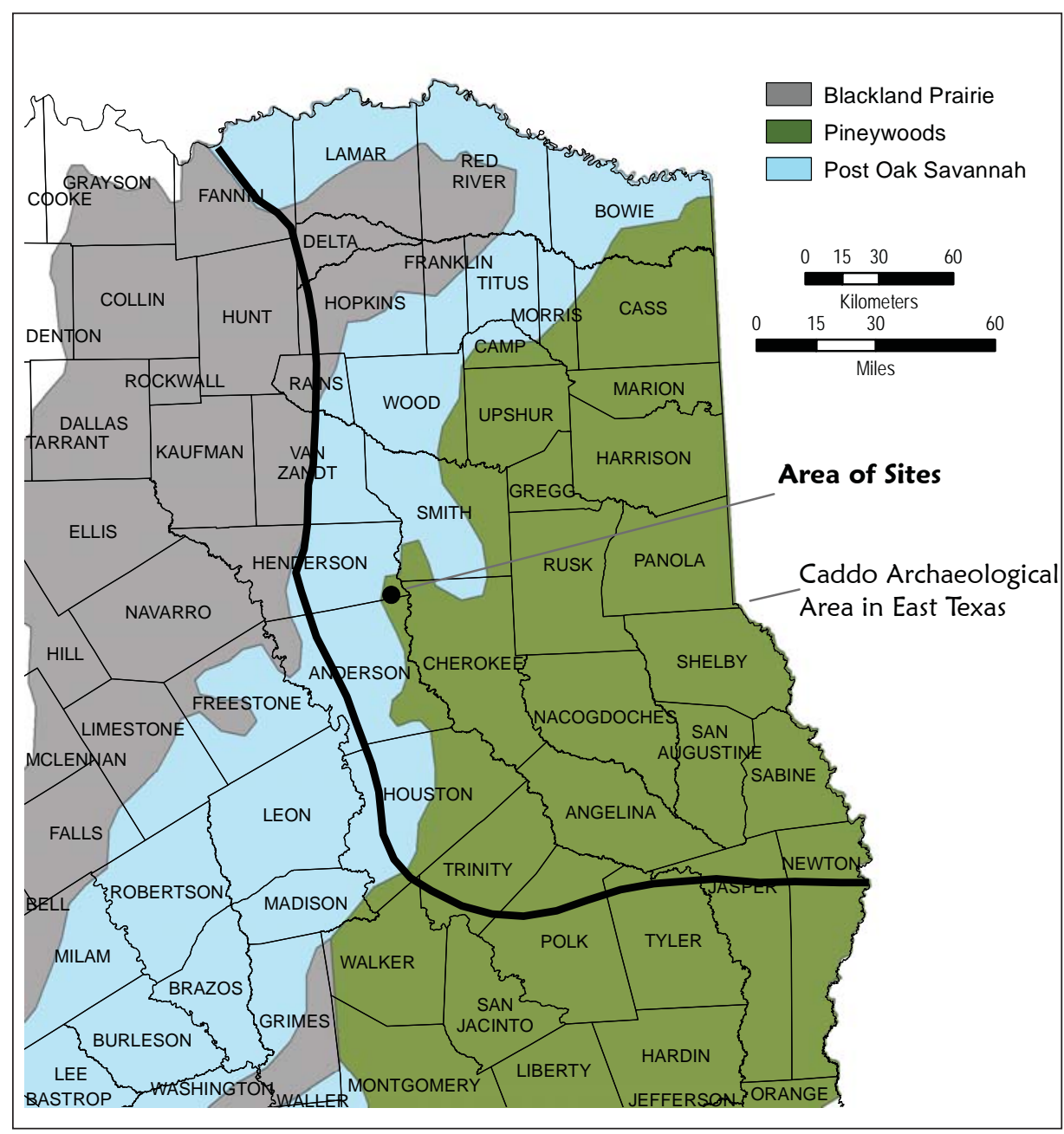

Figure 1. Location of the M. S. Roberts (41HE8) site and nearby A. S. Mann (41HE7/41AN201) site in East Texas. 


\section{Previous Archaeological Investigations}

This ancestral Caddo site was reported to Dr. J. E. Pearce of The University of Texas (UT) in September 1931 by Jeff D. Reagan of Palestine, Texas. In October 1931, a UT crew investigated the site, which had an earthen mound and an associated settlement (Pearce and Jackson 1931).

The site is on an alluvial terrace (ca. 430-450 ft. amsl) on the north side of Caddo Creek, an eastwardflowing tributary to the Neches River (Figure 2a); the mound is on the crest of the landform (Figure 2b). The M. S. Roberts site has a single earthen mound that was estimated in 1931 to be about $24 \times 20 \mathrm{~m}$ in length and width, and it was estimated to stand $1.7 \mathrm{~m}$ in height. A likely borrow pit depression was noted just to the west of the mound. Artifacts were noted and collected by Pearce and Jackson (1931) from the plowed surface of the mound and surrounding Caddo habitation areas on the alluvial terrace.

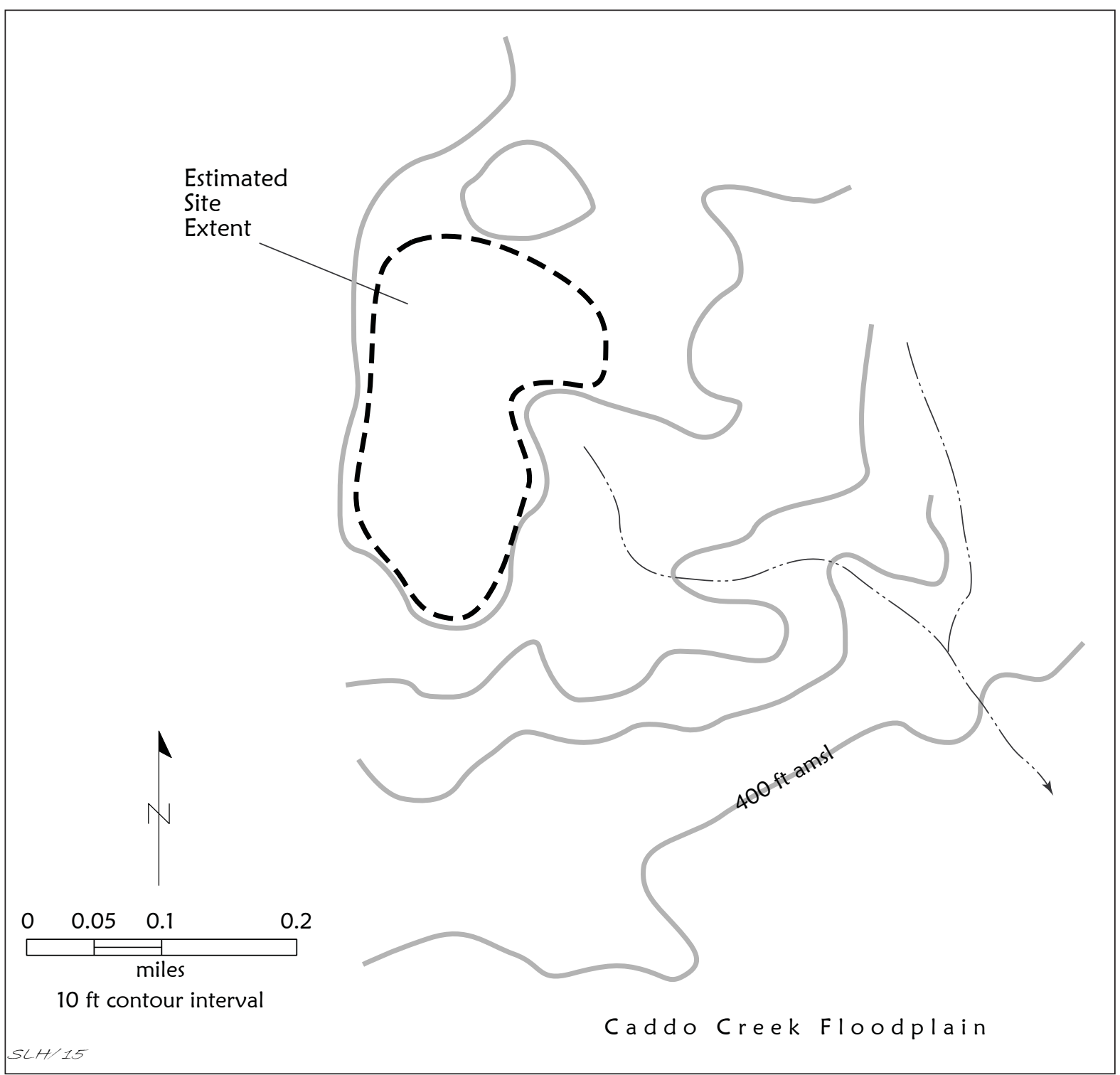

Figure 2a. Topographic setting of the M. S. Roberts site (41HE8) in the Caddo Creek valley in Henderson County, Texas: broad scale view. 


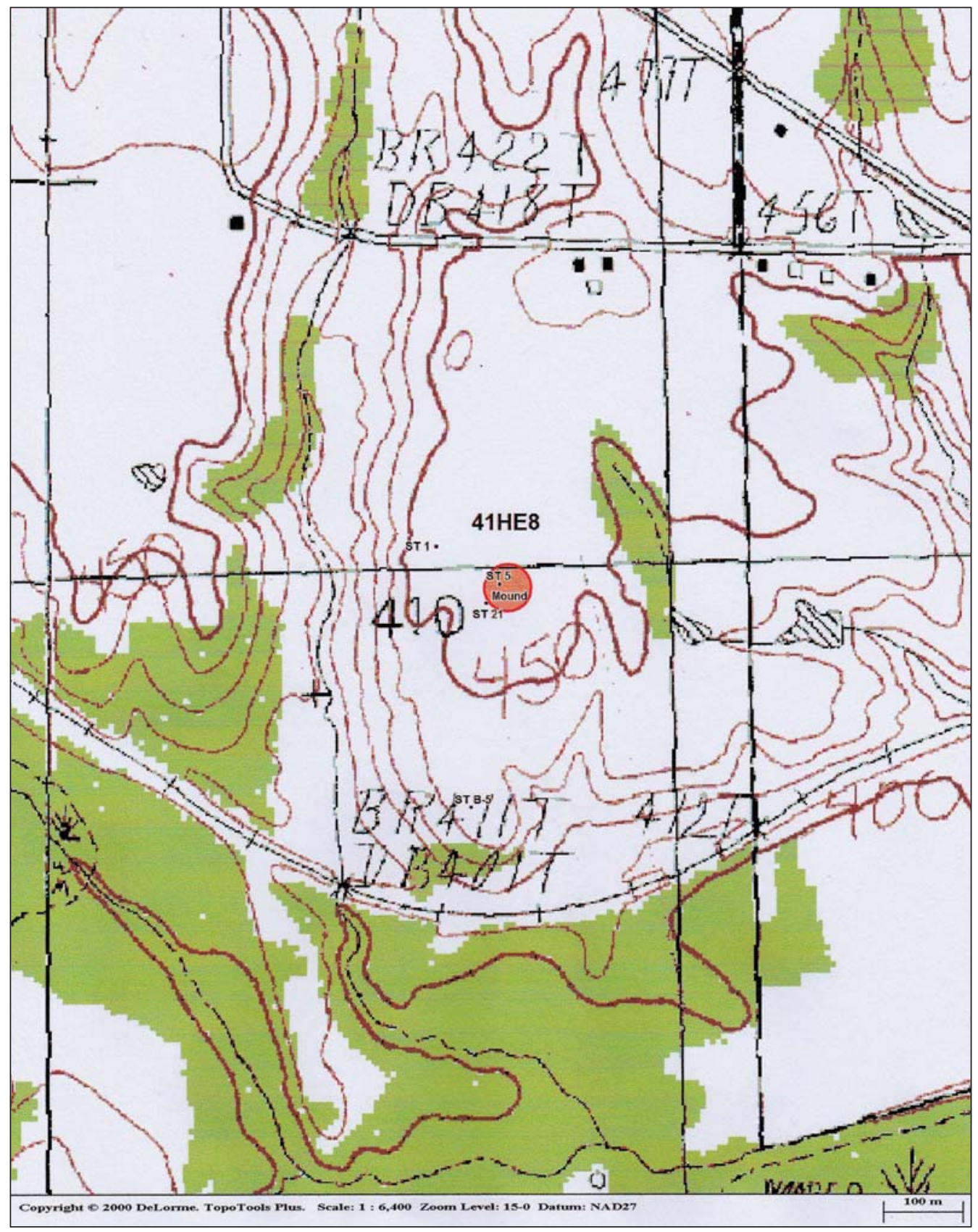

Figure 2b. Topographic setting of the M. S. Roberts site (41HE8) in the Caddo Creek valley in Henderson County, Texas: smaller-scale view, with the plotting of the mound on the Poynor USGS $7.5^{\prime}$ topographic quadrangle.

The 1931 UT work consisted of the excavation of an unknown number of trenches into the earthen mound. The trenches disclosed an undifferentiated mound fill from ca. 0-114 cm bs that had ash, ceramic sherds, and animal bones. The mound fill rested atop a clay floor (ca. 114-122 cm bs) from a burned structure, and this clay floor was placed atop the first mound fill zone, a yellow sand (ca. $122-146 \mathrm{~cm}$ bs) that also had unspecified associated midden materials. These first mound deposits were constructed on top of the natural ground surface, a brown sandy loam A- and E-horizon $(146-196+\mathrm{cm} \mathrm{bs})$. The mound at the M. S. Roberts site was undoubtedly built to cover an important Caddo structure, most likely a structure used for political and religious ceremonies or used as the residence of an important and elite member of the local Caddo community. 
There are 419 sherds from ceramic vessels in the Texas Archeological Research Laboratory (TARL) collections from the 1931 UT work at the M. S. Roberts site. This includes 253 plain sherds and 166 decorated sherds; the plain to decorated sherd ratio is 1.52 . The sherds from the site are from vessels tempered with either grog (i.e., crushed sherds) or burned bone. About 86 percent of the sherds are from grog-tempered vessels; more than 96 percent of the fine ware sherds are from grog-tempered vessels, compared to 84 percent of the utility wares. Overall, 14 percent of the sherds are from bone-tempered vessels: 15.9 percent of the utility wares but only 3.6 percent of the fine wares.

The principal decorative methods represented in the utility ware sherds from the 1931 collection at the M. S. Roberts site have incised ( $n=52,37.7$ percent), punctated $(n=39,28.3$ percent), and brushed $(n=28,20.3$ percent) decorative elements; another 4.3 percent of the sherds have brushed-incised or brushed-punctated decorative elements (Perttula 2016:Table 3). The incised sherds are likely from Maydelle Incised jars, as are several of the incised-punctated rim and body sherds (Figures 3 and 4). The sherds from vessels with brushing marks include one rim with horizontal brushing marks and body sherds with diagonal, opposed, overlapping, and parallel (probably oriented vertically) brushing marks on the vessel body. These are from Bullard Brushed jars (see Suhm and Jelks 1962:21). The few brushed-incised and brushed-punctated sherds are likely also from Bullard Brushed vessels with incised lines or punctations made through the brushing marks. The proportion of utility ware sherds with brushing marks ( 24.6 percent) in the M. S. Roberts assemblage is consistent with an early to mid- $15^{\text {th }}$ century ancestral Caddo occupations in the upper Neches River basin (see Anderson et al. 1974; Perttula 2011). Only after ca. A.D. 1400 do brushed sherds dominate Late Caddo period Frankston phase ceramic assemblages (Perttula 2011:162).

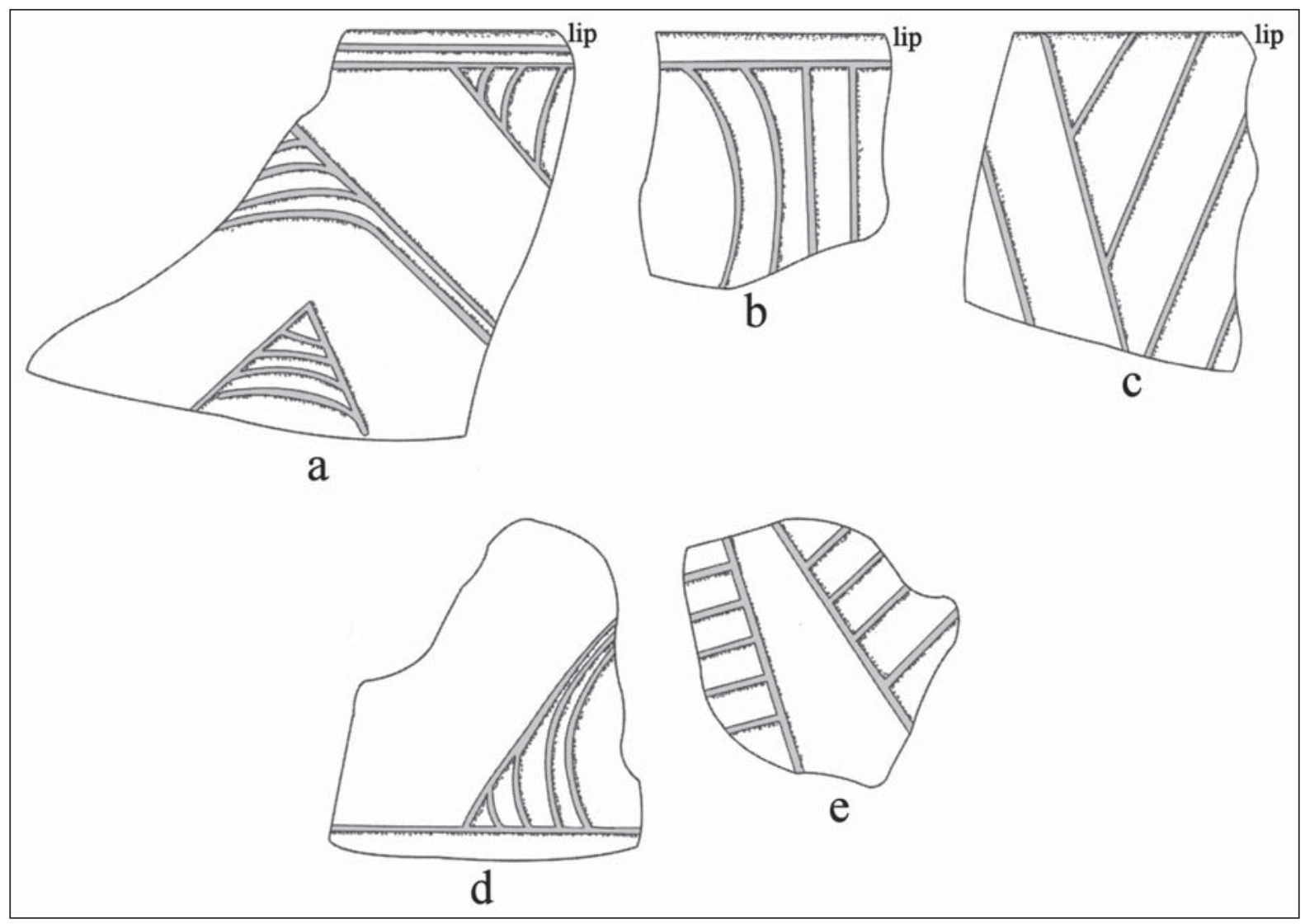

Figure 3. Selected incised decorative elements on sherds from the 1931 UT work at the M. S. Roberts site: a-c, rim sherds; d-e, body sherds. 


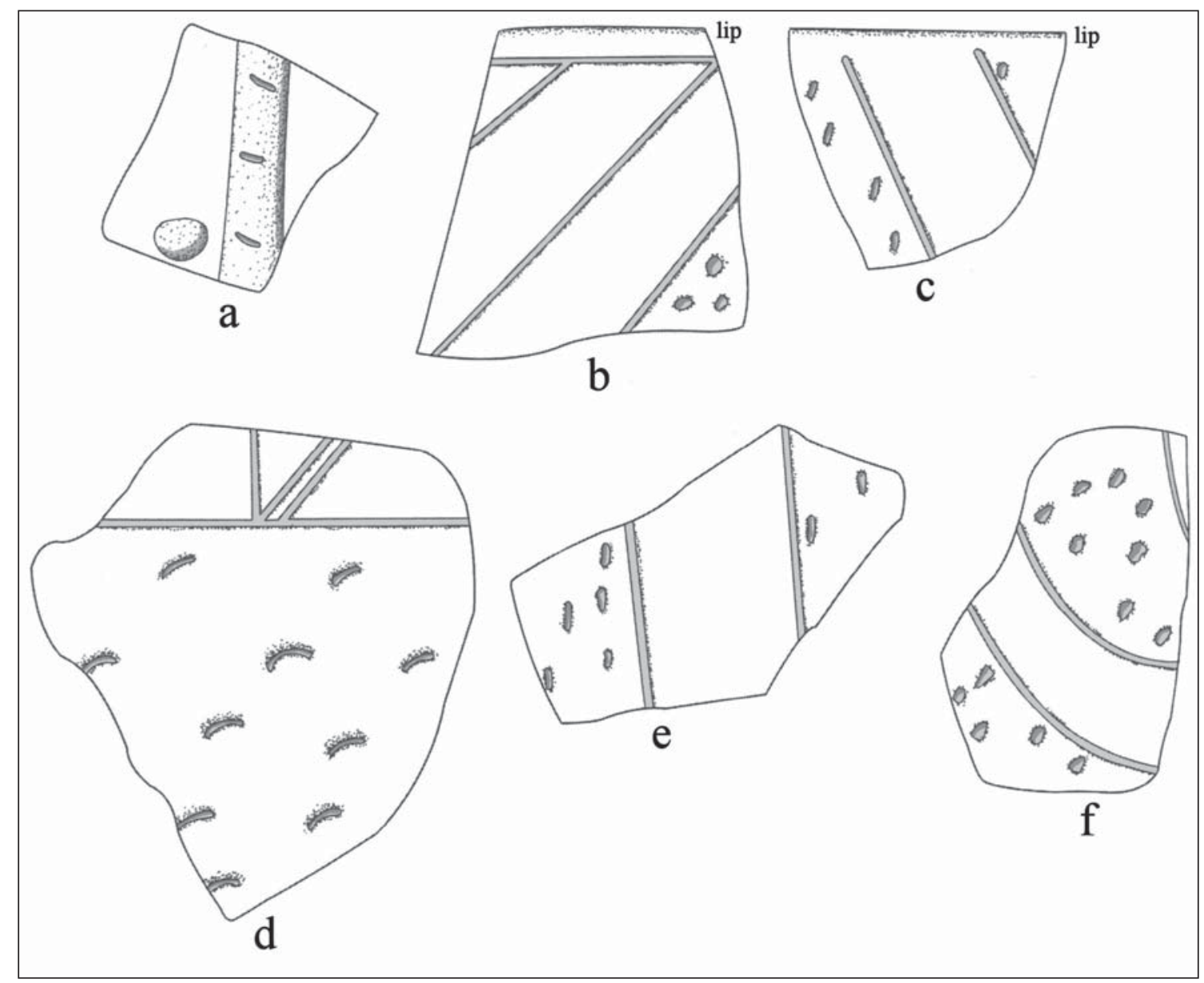

Figure 4. Selected appliqued and incised-punctated elements on sherds from the 1931 UT work at the M. S. Roberts site: a, appliqued; b-f, incised-punctated.

The fine ware sherds are from both engraved ( $n=21,75$ percent of the fine wares) and red-slipped ( $n=7$, 25 percent) vessels. The majority of the engraved sherds are from upper Neches River Poynor Engraved vessels (Figure 5a-g), including var. Blackburn (Figure 5f-g), var. Cook (Figure 5e), and var. unspecified with a slanting scroll and curvilinear hatched triangle attachments (Figure 5d). Others have diagonal, horizontal, and vertical hatched zones (Figure 5a-c). Both var. Blackburn and var. Cook vessels are most common in ca. A.D. 1400-1560 Frankston phase sites in the upper Neches River basin (Perttula 2011:Table 6-37). The proportion of red-slipped sherds - from both bowls, carinated bowls, and bottles - in the M. S. Roberts site fine wares is also notable, as red-slipped sherds are not generally common at all in upper Neches River basin sites, or indeed in ancestral Caddo sites in the Neches and Angelina river basins.

A single ceramic pipe sherd from the 1931 UT work was from a bone-tempered pipe with a thick (14.2 $\mathrm{mm}$ in diameter) long stem, possibly an L-shaped elbow pipe (Perttula 2011:215 and Figure 6-23); its stem hole opening was $6.0 \mathrm{~mm}$. This form of elbow pipe is the earliest elbow pipe style in the upper Neches River basin and has been found in ca. A.D. 1320 to ca. A.D. 1480 Middle Caddo period to Frankston phase components in the region (see Perttula et al. 2012:15).

The ceramic vessel sherds and elbow pipe sherd from the UT work at the M. S. Roberts site suggested that the Caddo construction of the mound and occupation of the settlement took place sometime in the first half of the $15^{\text {th }}$ century A.D. It may well have lasted until as late as ca. A.D. 1480, during the first part of the Frankston phase. 


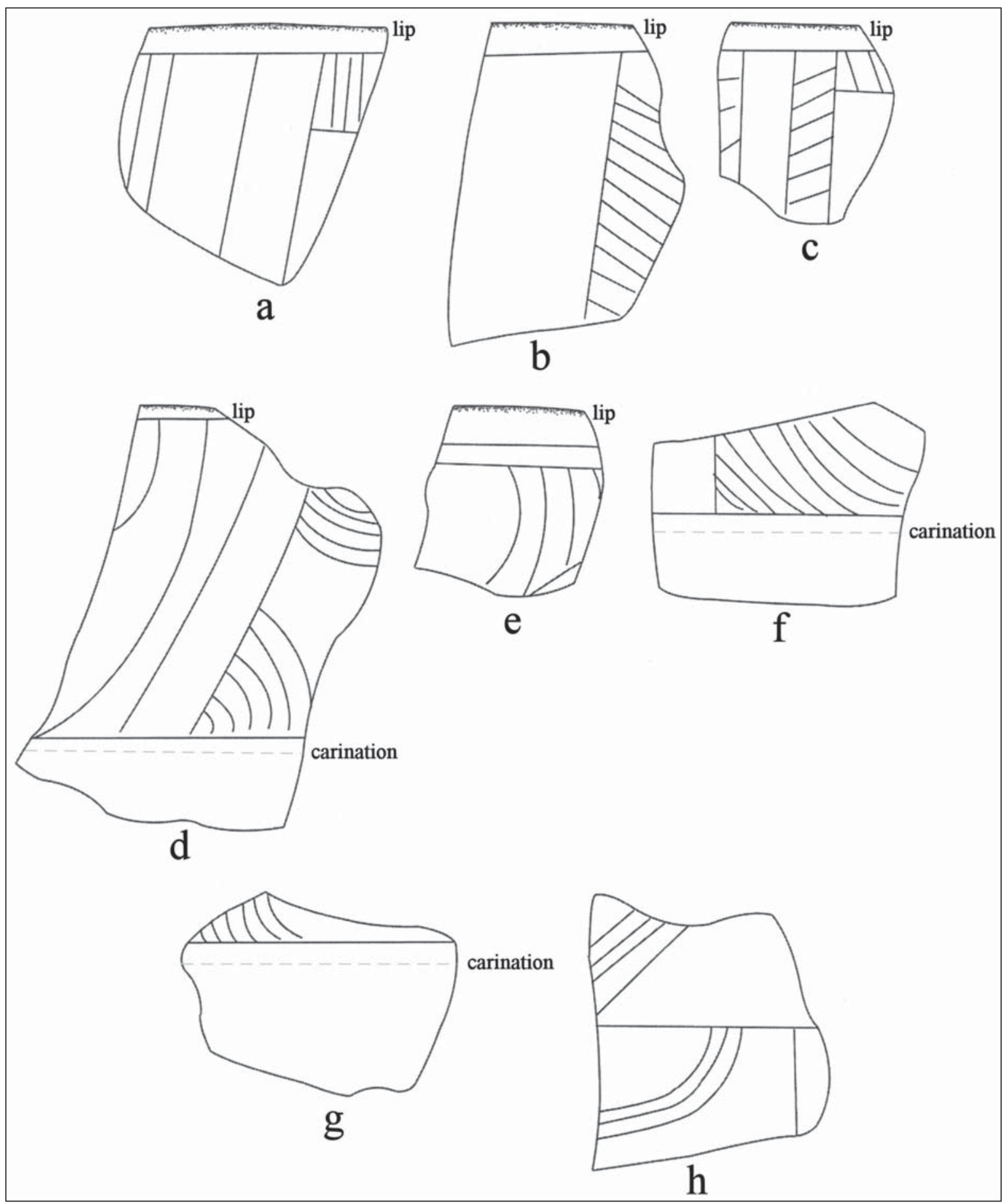

Figure 5. Selected decorative elements on engraved sherds from the 1931 UT work at the M. S. Roberts site: a-e, rim sherd; f-g, lower rim sherds; h, bottle sherd.

After a hiatus of more than 83 years from the Pearce and Jackson (1931) work, in January 2015, Mark Walters obtained, with the assistance of the landowners, a surface collection of artifacts from the M. S. Roberts site (41HE8), the long-forgotten ancestral Caddo mound center and settlement in the upper Neches River basin in Henderson County, Texas (Figure 6a-b). The January 2015 surface collection of Caddo artifacts from the site came from the mound itself (the mound stands about $1.8 \mathrm{~m}$ in height) as well as an apparently 
associated ca. $200 \times 200 \mathrm{~m}$ (ca. 10 acres) settlement and habitation areas. The majority of artifacts in the surface collection were ceramic sherds $(n=134)$ from ceramic vessels, but there were a few pieces of chipped stone debris $(\mathrm{n}=10)$ and a flake tool also visible on the surface (Perttula and Walters 2016).

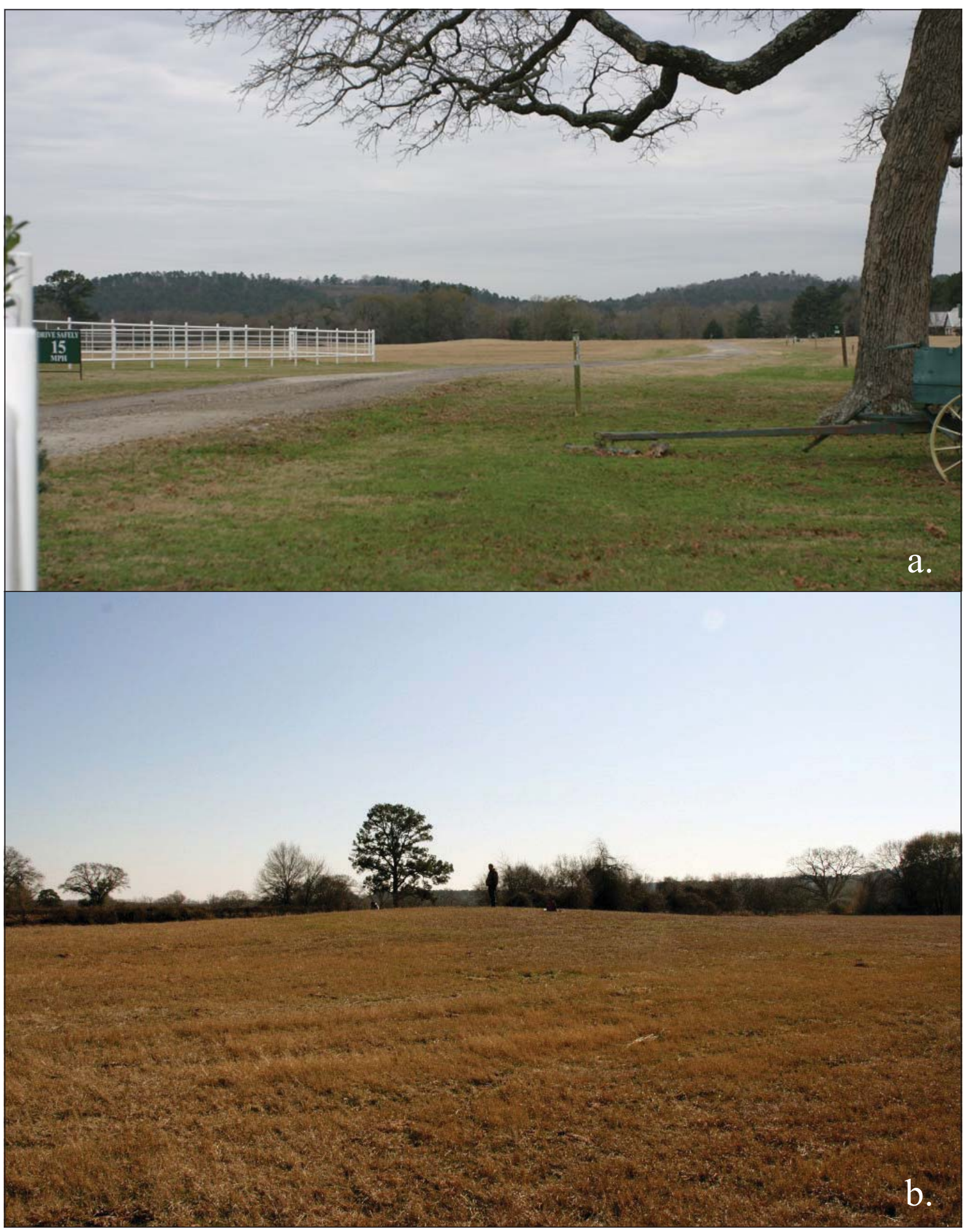

Figure 6 . The M. S. Roberts mound (41HE8): a, looking south at the mound and the surrounding pasture; $\mathrm{b}$, looking generally east at the mound. 
The January 2015 ceramic assemblage of sherds from plain ware, utility ware, and fine ware vessels were primarily grog-tempered, with considerable amounts of plain vessel rims and rim and body sherds from utility ware jars that were decorated with incised, punctated, brushed, and brushed-incised elements. Sherds from fine ware vessels were not well represented in the artifacts from the January 2015 surface collection, but there were sherds from both engraved bottles and carinated bowls as well as red-slipped bowls. Decorative elements on the engraved sherds were consistent with earlier varieties of Poynor Engraved, the principal fine ware type in the upper Neches River basin beginning in the $15^{\text {th }}$ century A.D. As with the collection of artifacts from the 1931 investigations completed by University of Texas archaeologists (Pearce and Jackson 1931; Perttula 2016), these artifacts suggested that the Caddo occupation of the settlement at the M. S. Roberts site took place sometime as early as in the first half of the $15^{\text {th }}$ century A.D., and the occupation may have lasted until as late as ca. A.D. 1480.

\section{June 2015 Work}

\section{Aerial Survey Work}

The aerial survey was completed using a DJI Phantom 2 quadrotor unmanned aerial vehicle (UAV) (Figure 7a-b) equipped with a Canon SD4000 IS 10 MP camera. Twelve aerial targets were placed over the survey area and the locations of each target were recorded with a WAAS-enabled Garmin 62S GPS averaging 3 minutes per point.

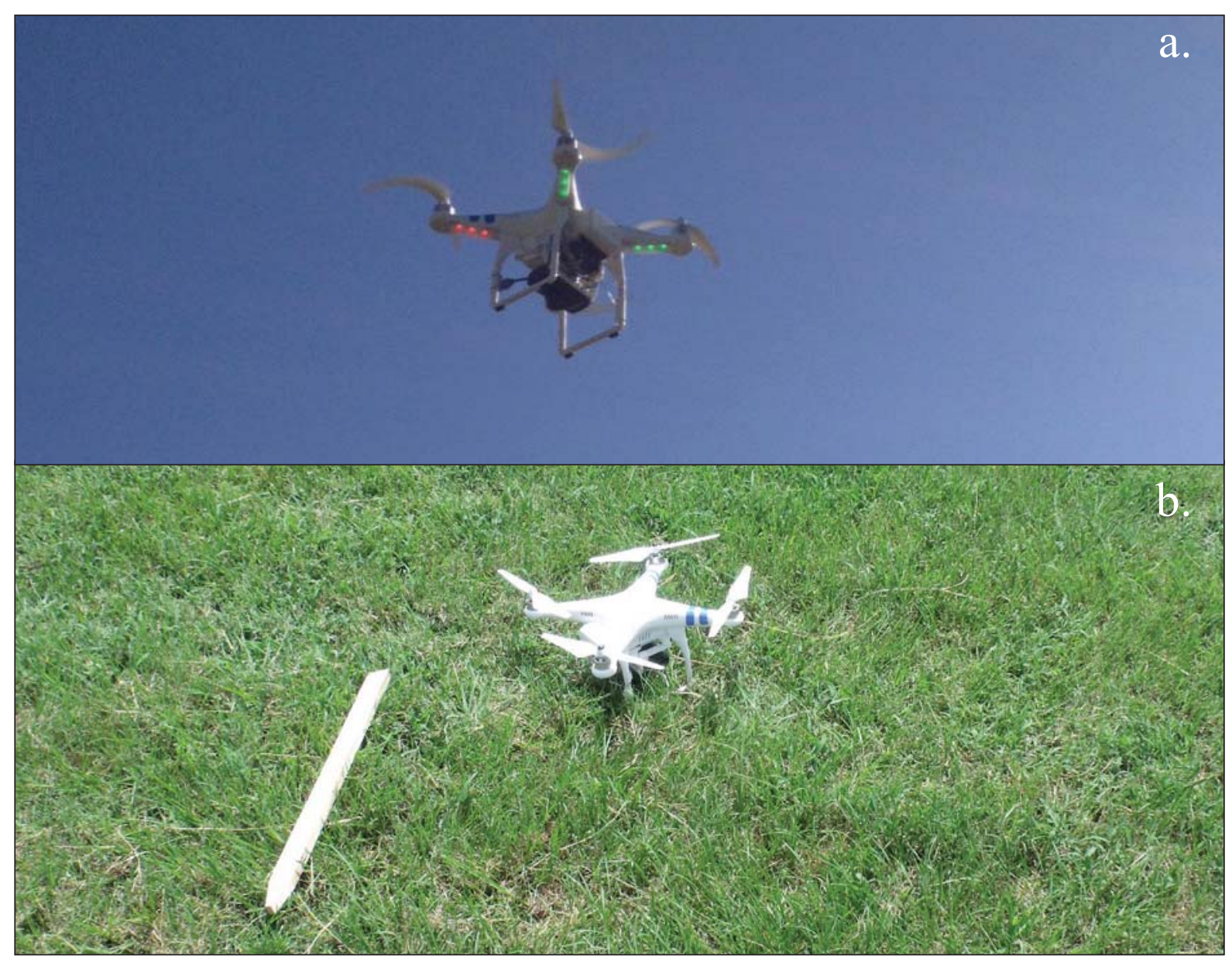

Figure 7. The DJI Phantom 2 quadrotor unmanned aerial vehicle used in the aerial survey work at the M. S. Roberts site (41HE8): a, in the air; b, stationary. 
Prior to the initiation of the field survey a flight plan was generated in ArcGIS using the property boundary, camera specifics, and desired image resolution and photo overlap as inputs for the Photo Survey Planner Add-In developed by Arlo McKee (Table 1). This resulted in the automatic generation of survey waypoints to cover the survey area at a regular grid spacing. The camera was set to shutter priority mode and set to capture images at approximately 2.8 second intervals. The instructions for each flight path were sent to the DJI Ground Station software to allow for the UAV to autonomously fly the regular survey grid. This resulted in the capture of 1079 images and an overlap of generally 38 images over most of the study area.

Table 1. Input parameters for the aerial survey.

\begin{tabular}{|l|l|l|l|l|l|l|l|}
\hline $\begin{array}{l}\text { Camera } \\
\text { focal } \\
\text { length }\end{array}$ & $\begin{array}{l}\text { Sensor } \\
\text { dimensions } \\
(\mathrm{mm})\end{array}$ & $\begin{array}{l}\text { Image } \\
\text { dimensions } \\
(\text { pixels })\end{array}$ & $\begin{array}{l}\text { Shutter } \\
\text { speed } \\
(\mathrm{s})\end{array}$ & $\begin{array}{l}\text { Altitude } \\
(\mathrm{m})\end{array}$ & $\begin{array}{l}\text { Flight } \\
\text { speed } \\
(\mathrm{m} / \mathrm{s})\end{array}$ & $\begin{array}{l}\text { Transect } \\
\text { spacing } \\
(\mathrm{m})\end{array}$ & $\begin{array}{l}\text { Approxi- } \\
\text { mate photo } \\
\text { spacing }(\mathrm{m})\end{array}$ \\
\hline $4.9 \mathrm{~mm}$ & $6.22-\mathrm{X}-4.17$ & $\begin{array}{l}3648-\mathrm{X}- \\
2736\end{array}$ & $1 / 400$ & 25.5 & 3 & 11.58 & 8.54 \\
\hline
\end{tabular}

The images were then loaded into Agisoft Photoscan Pro and a 3D model was generated. Photoscan uses the SIFT method (Lowe 2004) to calculate the 3D positions of objects captured in multiple unordered overlapping images. This method is commonly known as Structure-from-Motion and due to the relatively number of input requirements it has been widely applied to archaeological and geomorphological applications (e.g., Gonçalves and Henriques 2015; Hesse 2015; Lerma and Muir 2014; Martínez et al. 2015; Sanger 2015; Tonkin et al. 2014). The primary limitation on the accuracy of data generated from this method arises from the Ground Sample Distance (GSD) of the input photographs. The GSD (after Gonçalves and Henriques $2015)$ can be determined by the input camera distance $\left(H_{d}\right)$, lens focal length $(f)$, sensor width $\left(S_{w}\right)$, and image pixel width $\left(P_{w}\right)$ as:

$$
G S D=\left(H_{d} S_{w}\right) /\left(f P_{w}\right)
$$

Camera motion during the survey does slightly limit the input GSD due to image blur, but the resulting GSD from the survey was $0.779 \mathrm{~cm} /$ pix. Given that most case studies have yielded results that suggest that the precision of the resulting 3D elevation data from this method can be expected at $1-1.4 \mathrm{x}$ GSD (Colomina and Molina 2014), the resulting vertical accuracy of the dataset should be within $1.09 \mathrm{~cm}$. This distance is well within the variation of vegetation height during the time of the survey.

After the photos were aligned, a digital 3D surface was generated in Photoscan, and the data was exported to ArcGIS for additional processing. Both a digital elevation model (DEM) and a seamless orthophoto were exported at a $1 \mathrm{~cm}$ resolution. In order to accurately represent the ground surface heights, rather than vegetation height, additional processing was necessary. To accomplish this, the DEM was first detrended and converted from relative sea level elevation (m AMSL) using a $2^{\text {nd }}$ order Global Polynomial Interpolation. This detrending process helps to remove additional artificial curvature that the camera calibration in Photoscan does not automatically process out of the data. To filter the influence of vegetation and approximate the ground surface elevation, the data was additionally sent through a $1^{\text {st }}$ order Local Polynomial Interpolation with a filter radius of $1 \mathrm{~m}$. This resulted in a relatively smooth representation of the ground surface with the natural terrace height trending toward a relative elevation of $0 \mathrm{~m}$. The resulting elevation dataset ranged from a low of approximately $2.7 \mathrm{~m}$ below the average terrace elevation below the scarp in the northwest part of the study area to a high of approximately $1.7 \mathrm{~m}$ near the artificially terraced edge of the landform. Additional erroneous points sampled from buildings and trees extended the dataset to $18 \mathrm{~m}$.

The mound and borrow pit features were delineated through examining the DEM and a $10 \mathrm{~cm}$ contour interval. The mound was clearly visible as a slightly oblong feature extending from baseline elevation to a maximum height of $91 \mathrm{~cm}$ within an aerial extent of $855 \mathrm{~m}^{2}$ (Figure 8). The edges of the borrow pit are not 
as clearly defined as the mound, but a clear isolated depression is visible extending from $56 \mathrm{~cm}$ below the baseline elevation to a maximum depth of $87 \mathrm{~cm}$ (Figure 9). In this way, the aerial extent of the borrow pit is mapped as encompassing $2000 \mathrm{~m}^{2}$, although it is likely that the maximum extent of borrowing is beyond this mapped extent. Based on these extents both the mound and borrow pit volumes can be calculated relative to the baseline elevation. The volume of the mound is calculated as 313.68 cubic meters, while the total volume represented by the known borrow pit area is 270.82 cubic meters, or 86 percent of the total estimated mound volume. This is also estimated by the boundary drawn on the figure. This leaves an estimated 42.86 cubic meters of fill in the mound unaccounted for, or perhaps the borrow pit contains fill from the mound that has washed in after the site began to be plowed in the $20^{\text {th }}$ century. It is important to also note that north and northeast of the mound are subtly low-lying areas of the terrace that, when viewing the mound from these locations, gives the impression that the mound is taller above the terrace level than it actually is (Figures 10 and 11). Whether these were artificially lowered areas or that the Caddo mound builders took advantage of this natural feature would need further subsurface testing. Figure 12 shows these areas from a vertical exaggerated 3D perspective.

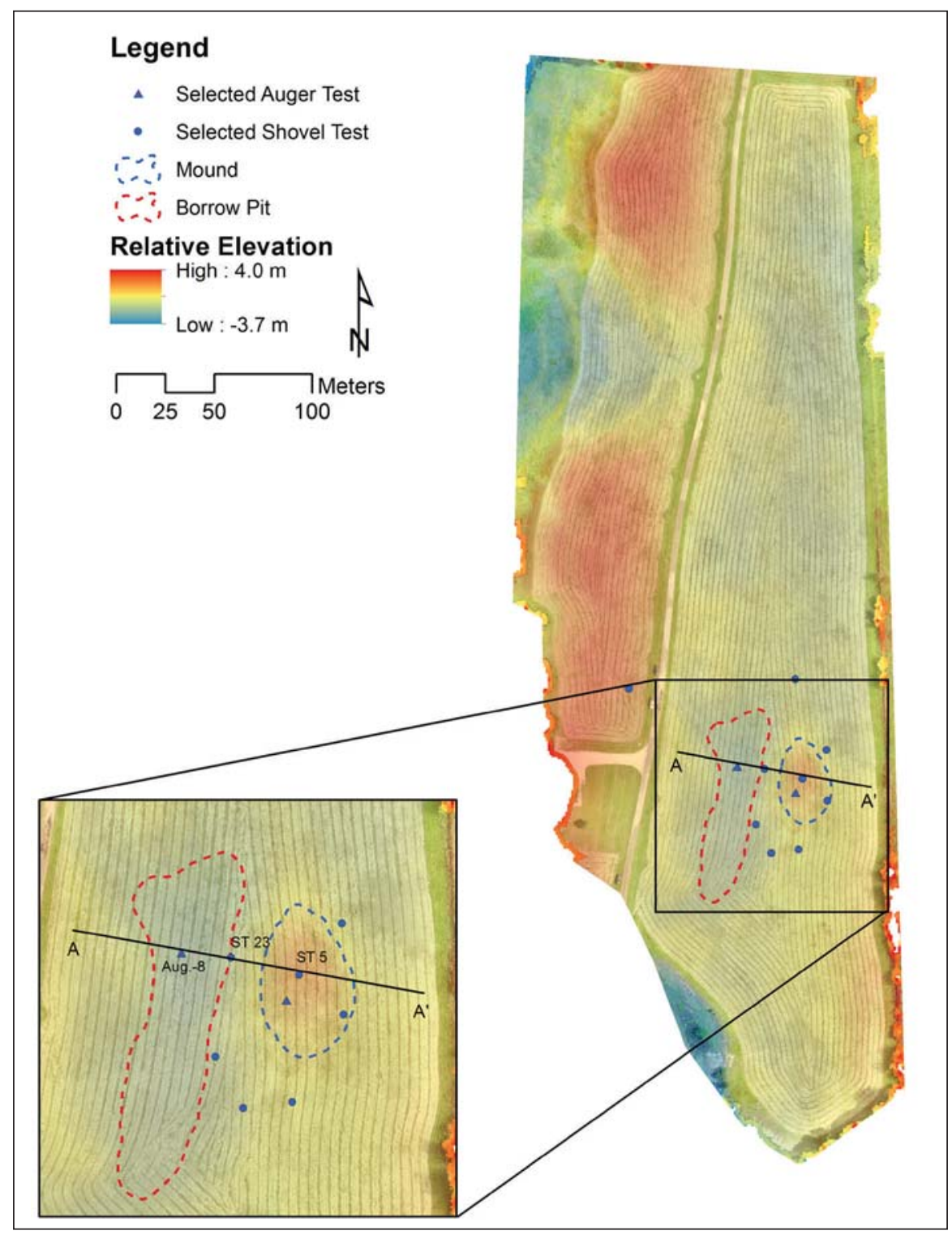

Figure 8. Map showing the DEM and orthophoto overlay of the 41HE8 study area. The locations of representative shovel tests and an artificial cross section (A) through the mound and borrow pit are also shown. 


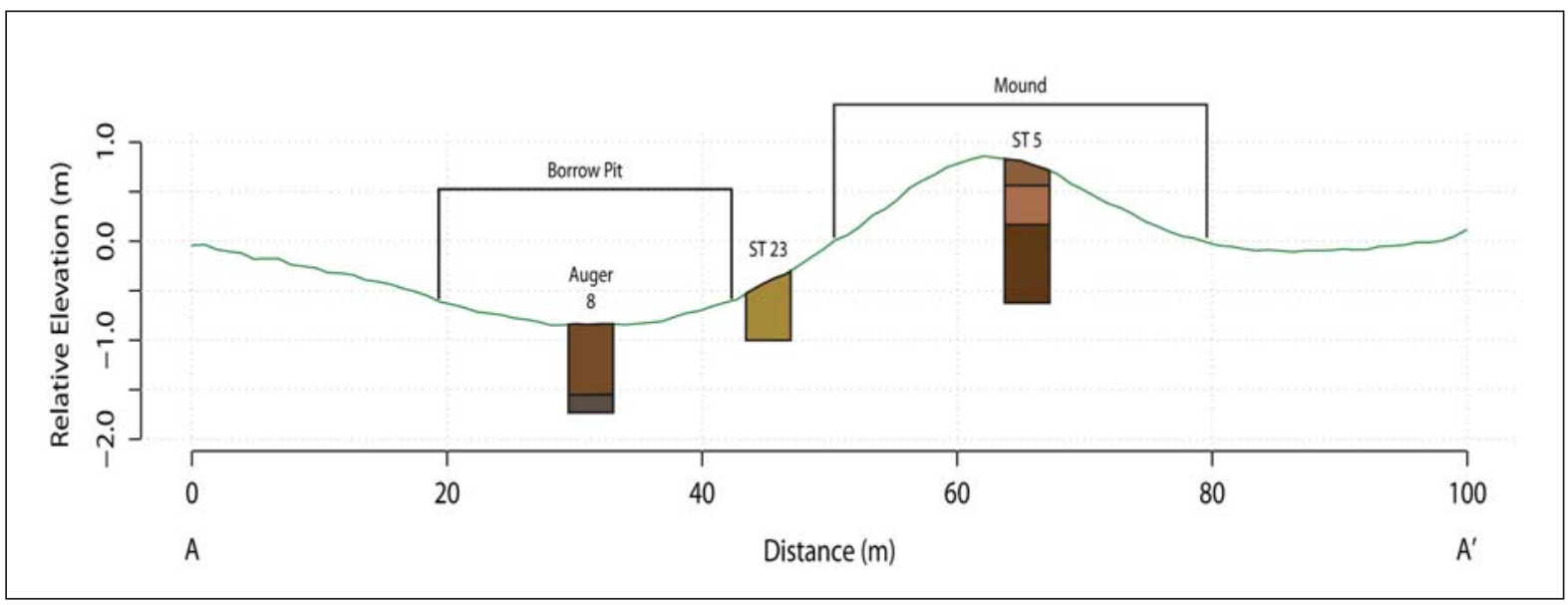

Figure 9. A cross section showing the variation of the ground surface across the mound and borrow pit features.

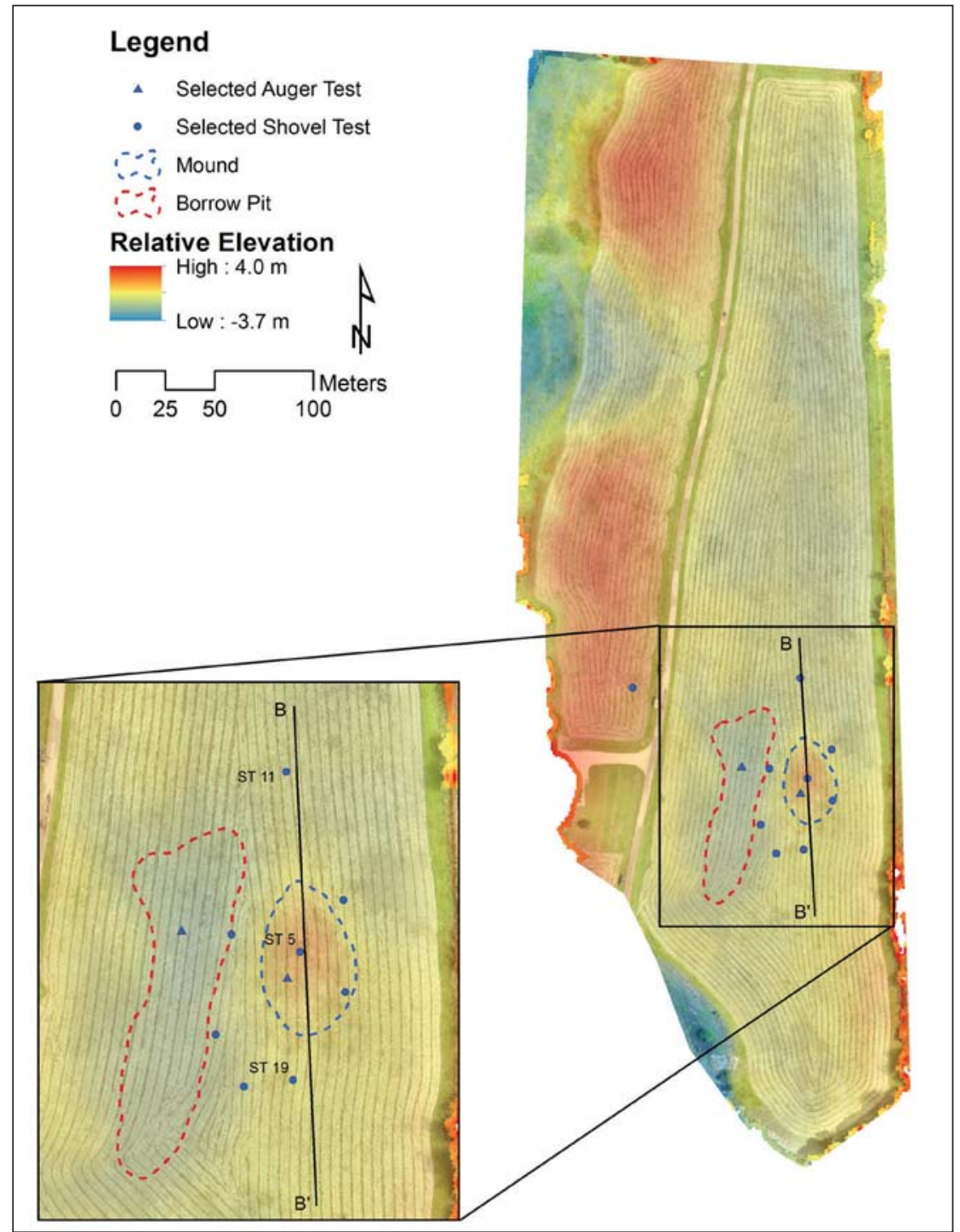

Figure 10. Map showing the DEM and orthophoto overlay of the 41HE8 study area. The locations of representative shovel tests and an artificial cross section (B) through the mound and low lying area to the north are also shown. 


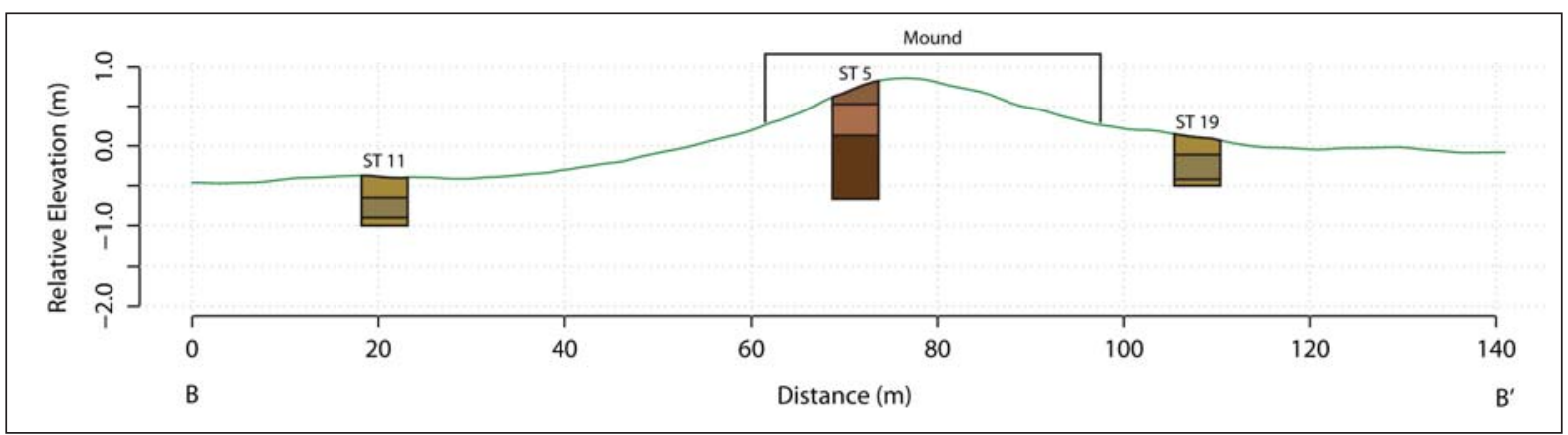

Figure 11. A cross section showing the variation of the ground surface across the mound adjacent terrace surfaces

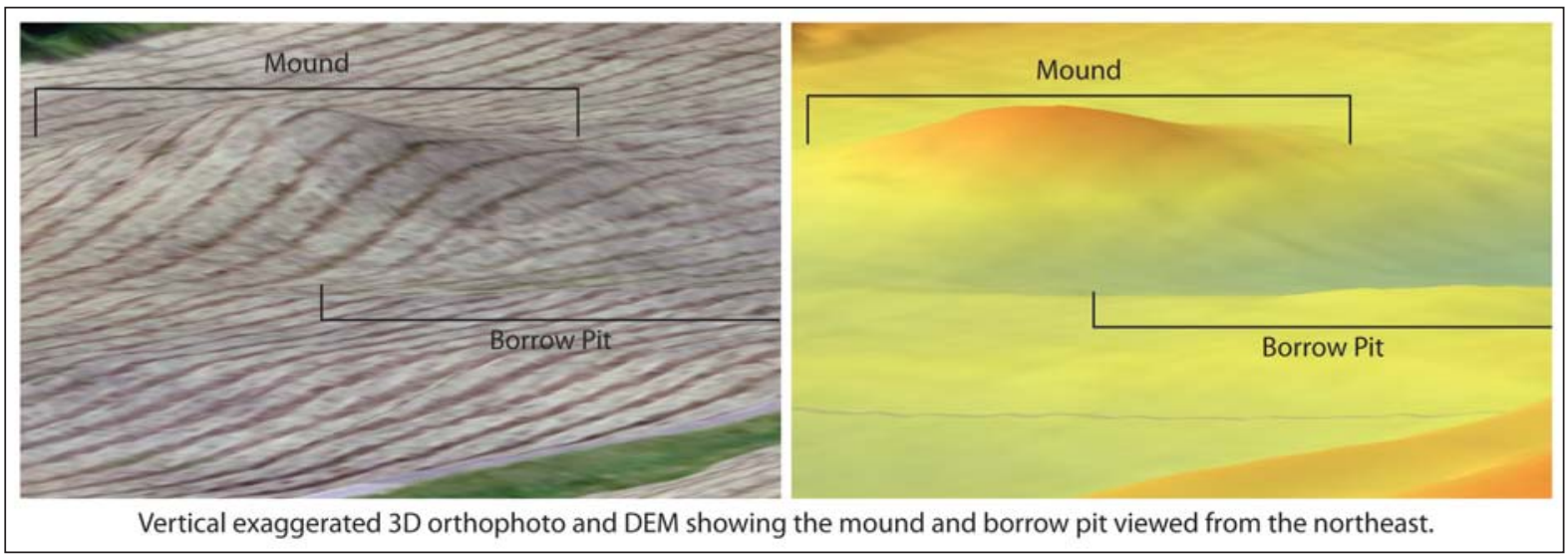

Figure 12. Images showing the vertical exaggerated 3D orthophoto and DEM showing the mound and borrow pit viewed from the northeast.

\section{Shovel Testing}

The first round of shovel testing took place on the western part of the landform, more than $60 \mathrm{~m}$ west to southwest of the mound, which is on the eastern side of the property road. This includes ST 1-4 and ST B-1 to ST B-4, spaced about 20-30 m apart in two north-south rows. Single pieces of lithic debris were recovered in ST 1 (20-40 cm bs), ST $3(0-20 \mathrm{~cm} \mathrm{bs})$, ST 4 (20-40 cm bs), and ST B-4 (40-60 cm bs); no Caddo ceramics were found in this part of the site.

Sediment descriptions for these shovel tests are as follows:

ST 1: 0-80 $\mathrm{cm}^{+}$, yellowish-brown sandy loam;

ST 2: 0-65 cm, yellowish-brown sandy loam; $65-75 \mathrm{~cm}+$, orangish-brown loam;

ST 3: 0-60 cm+, yellowish-brown sandy loam;

ST 4: 0-60 cm+, yellowish-brown sandy loam;

ST B-1: 0-102 cm+, yellowish-brown sandy loam;

ST B-2: 0-100 cm+, yellowish-brown sandy loam; 
ST B-3: 0-89 cm+, yellowish-brown sandy loam; and

ST B-4: 0-86 cm+, yellowish-brown sandy loam.

Two other shovel tests (ST B-5 and ST B-6) were excavated at the southern tip of the landform, about $300 \mathrm{~m}$ south of the mound. The A/E-horizon yellowish-brown sandy loam sediments ranged between 37-41 $\mathrm{cm}$ thick overlying a strong brown clay B-horizon. Neither shovel test contained any archaeological deposits.

All of the shovel tests on the eastern side of the site and property road, including ST 5 in the mound as well as ST 9-24 around and near the mound, contain archaeological deposits from 0-60 $\mathrm{cm}$ bs with a considerable density of ancestral Caddo sherds (Figure 13). These shovel tests cover a ca. 100 x $50 \mathrm{~m}$ area, but the overall extent of the archaeological deposit at the site has not been established through this shovel testing effort.

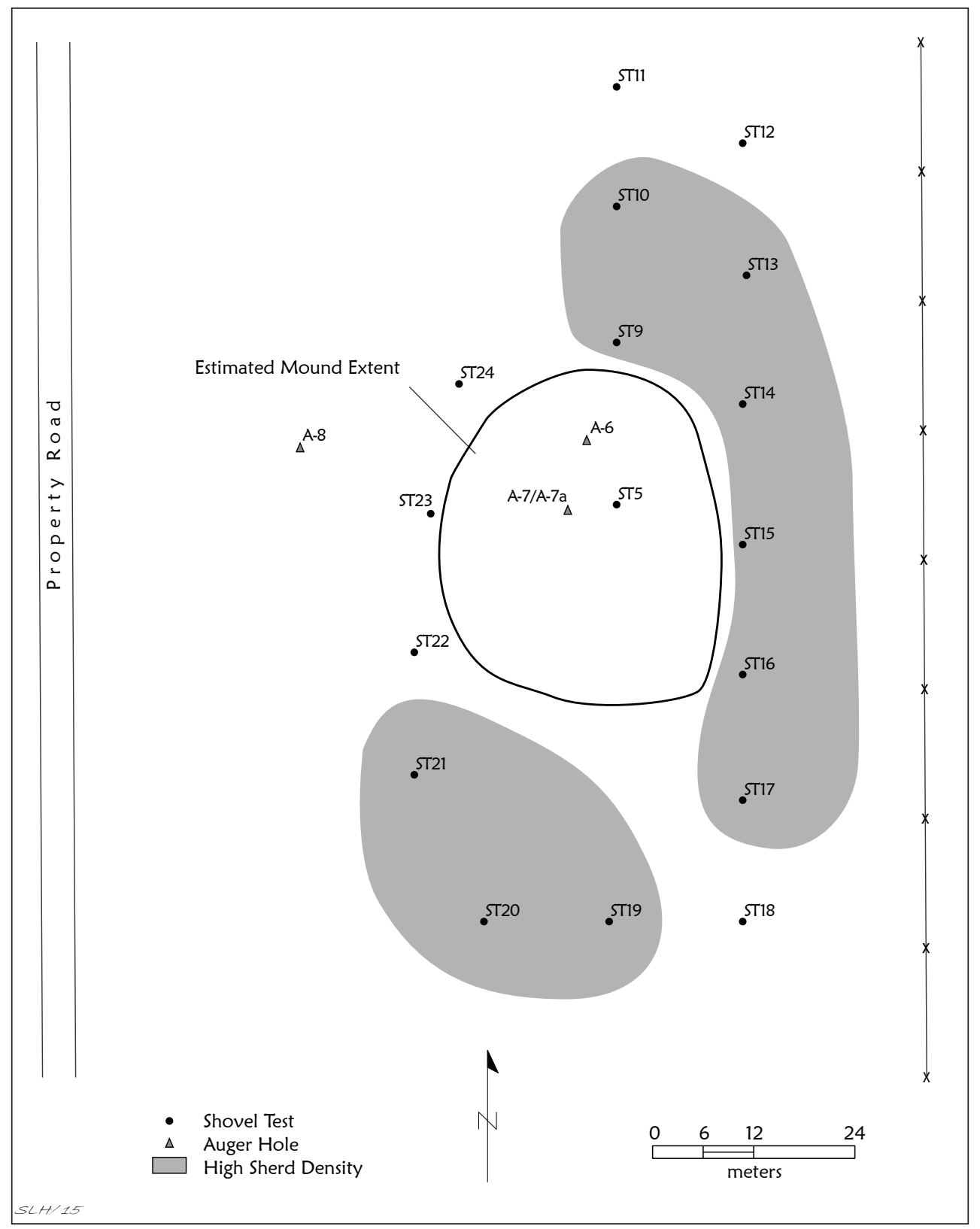

Figure 13. Location of ST 5, and 9-24, and Auger holes 6, 7, 7a, and 8 at the M. S. Roberts site. 
The sediment descriptions for ST 5 and ST 9-24 are:

ST 5: 0-20 cm, brown sandy loam with red and gray clay; $20-60 \mathrm{~cm}+$, dark reddish-brown sandy loam and red and gray clay chunks; an auger hole was subsequently excavated from $60-140 \mathrm{~cm}$ bs in this shovel test (see below);

ST 9: 0-35 cm, yellowish-brown sandy loam; $35-55 \mathrm{~cm}$, dark yellowish-brown sandy loam; 55-60 cm+, yellowish-brown sandy loam;

ST 10: 0-28 cm, yellowish-brown sandy loam; $28-53 \mathrm{~cm}$, dark yellowish-brown sandy loam; 53-60 cm+, yellowish-brown sandy loam;

ST 11: 0-25 cm, yellowish-brown sandy loam; $25-50 \mathrm{~cm}$, dark yellowish-brown sandy loam; 50-60 cm+, yellowish-brown sandy loam;

ST 12: 0-21 cm, yellowish-brown sandy loam; $21-55 \mathrm{~cm}$, dark yellowish-brown sandy loam; 55-60 cm+, yellowish-brown sandy loam;

ST 13: 0-23 cm, yellowish-brown sandy loam; $23-48 \mathrm{~cm}$, dark yellowish-brown sandy loam; 48-60 cm+, yellowish-brown sandy loam;

ST 14: 0-20 cm, yellowish-brown sandy loam; $27-52 \mathrm{~cm}$, dark yellowish-brown sandy loam; 52-60 cm+, yellowish-brown sandy loam;

ST 15: 0-24 cm, yellowish-brown sandy loam; $24-53 \mathrm{~cm}$, dark yellowish-brown sandy loam; 53-60 cm+, yellowish-brown sandy loam;

ST 16: 0-24 cm, yellowish-brown sandy loam; $24-53 \mathrm{~cm}$, dark yellowish-brown sandy loam; 53-60 cm+, yellowish-brown sandy loam;

ST 17: 0-24 cm, yellowish-brown sandy loam; $24-50 \mathrm{~cm}$, dark yellowish-brown sandy loam; 50-60 cm+, yellowish-brown sandy loam;

ST 18: 0-52 cm, yellowish-brown sandy loam; $52-60 \mathrm{~cm}+$, light yellowish-brown sandy loam;

ST 19: 0-21 cm, yellowish-brown sandy loam; $21-52 \mathrm{~cm}$, dark yellowish-brown sandy loam; 52-60 cm+, yellowish-brown sandy loam;

ST 20: 0-24 cm, yellowish-brown sandy loam; $24-51 \mathrm{~cm}$, dark yellowish-brown sandy loam; 51-60 cm+, light yellowish-brown sandy loam;

ST 21: 0-25 cm, yellowish-brown sandy loam; $25-51 \mathrm{~cm}$, dark yellowish-brown sandy loam; 51-60 cm+, light yellowish-brown sandy loam;

ST 22: 0-60 cm+, yellowish-brown sandy loam;

ST 23: 0-60 $\mathrm{cm}+$, yellowish-brown sandy loam;

ST 24: 0-26 cm, yellowish-brown sandy loam; $26-50 \mathrm{~cm}+$, dark yellowish-brown sandy loam; moisture increases in sediments below $40 \mathrm{~cm}$ bs. 
Many of the shovel tests have a shallowly buried (ca. $20-25 \mathrm{~cm}$ bs to ca. $50 \mathrm{~cm}$ bs) dark yellowishbrown sandy loam deposit with charcoal flecks and numerous sherds. This sediment zone likely represents the unplowed portions of the Caddo habitation deposits at the site. The highest densities of ceramic vessel sherds are in shovel tests to the south and southwest of the mound as well as north, east, and southeast of the mound (see Figure 13).

\section{Mound Augering}

Auger holes were excavated in the mound (below $60 \mathrm{~cm}$ bs in ST 5 and A-6, A-7, and A-7a) as well as in a likely low borrow pit area about $20 \mathrm{~m}$ west of the northern part of the mound at the M. S. Roberts site (Figure 14). The profiles in the mound have a variety of mound fill zones, including sandy loams, clay loams, and a mixture of sandy loam and red and gray clay chunks. Auger hole excavations in ST 5 and A-6 encountered a very dark sandy loam zone between $102-135 \mathrm{~cm}$ bs (A-6) and $120-140 \mathrm{~cm}$ bs (ST 5) (Figure 14) that may represent the remains of a burned structure encountered during the 1931 UT work. No clay floor was encountered in any of the auger holes, but significant amounts of gray clay chunks were noted in A-7a between $83-119 \mathrm{~cm}$ bs, nor was a basal yellow sand mound zone in our auger holes. The base of the mound may lie at ca. $140 \mathrm{~cm}$ bs, with underlying dark yellowish-brown or yellowish-brown sandy loam or sand deposits representing the buried A- and E-horizons on the landform.

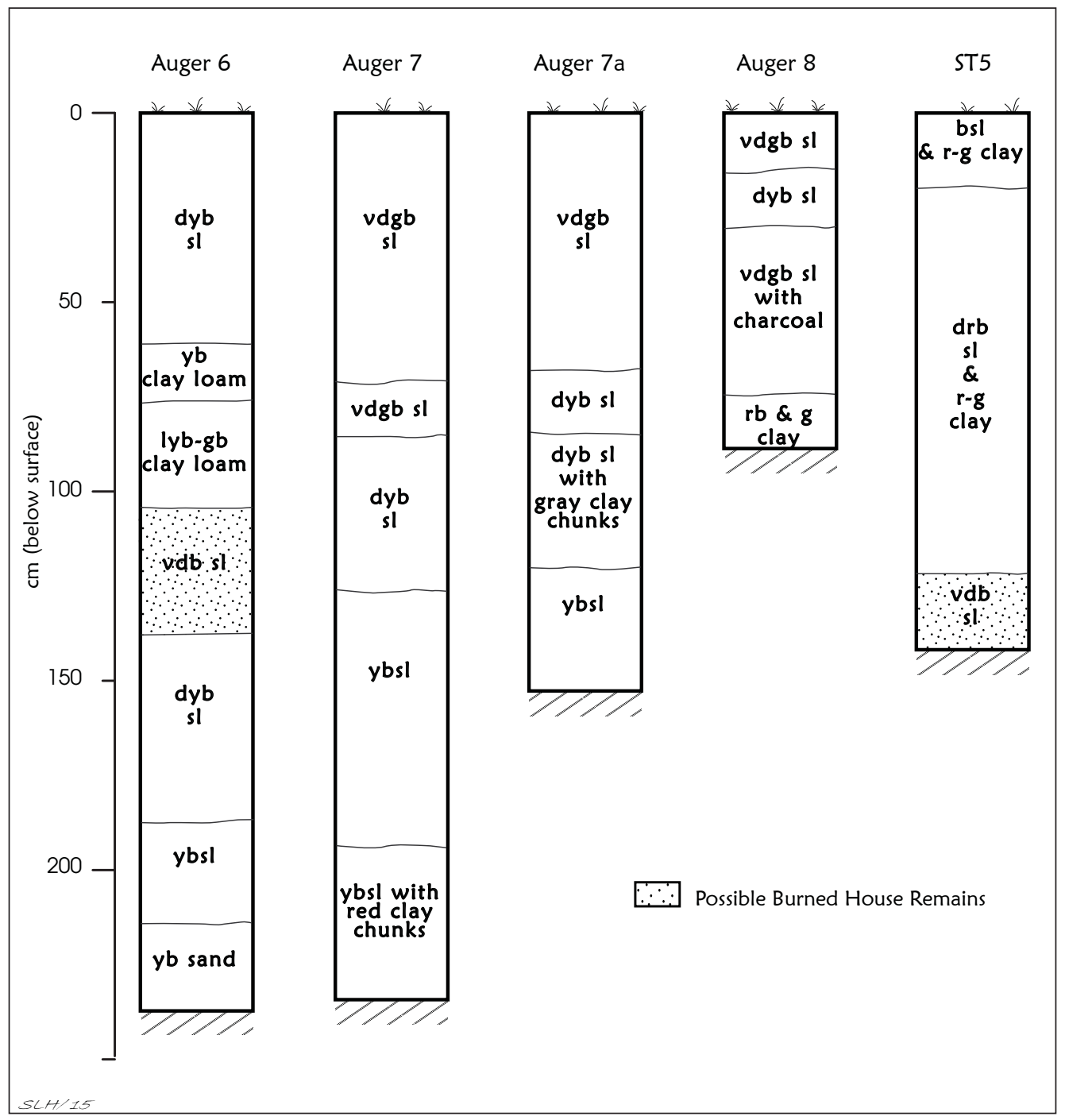

Figure 14. Recorded profiles in ST 5 and Auger holes 6, 7, 7a, and 8. 
The auger hole excavated in the likely borrow pit (A-8) west of the mound encountered shallow very dark grayish-brown and dark yellowish-brown sandy loam sediments, some with notable charcoal flecks, between $0-72 \mathrm{~cm}$ bs (see Figure 14). These sediments overlie a zone of reddish-brown and gray clay to at least ca. $90 \mathrm{~cm}$ bs.

\section{Recovered Caddo Artifacts}

A total of 248 artifacts have been recovered in the June 2015 archaeological investigations at the M. S. Roberts site, including a general site surface collection obtained by Denise Roberts. Twenty-one shovel tests contain archaeological remains, including plain and decorated sherds (from 17 shovel tests), one chipped stone tool fragment from ST 17, lithic debris (from 10 shovel tests), animal bone (ST 20), burned clay (ST 21), and a ceramic pipe sherd (ST 21). On the western part of the landform, only lithic debris was recovered in the shovel testing investigations (Table 2).

Table 2. Recovered artifacts in the June 2015 archaeological investigations at the M. S. Roberts site.

\begin{tabular}{|c|c|c|c|c|c|c|c|c|c|}
\hline Provenience & PS & DS & $\mathrm{AP}$ & Tool & LD & Bone & $\mathrm{BC}$ & $\begin{array}{l}\text { Pipe } \\
\text { Sherd }\end{array}$ & $\mathrm{N}$ \\
\hline Surface & 25 & 10 & 1 & - & - & - & - & - & 36 \\
\hline ST B-4 & - & - & - & - & 1 & - & - & - & 1 \\
\hline ST 1 & - & - & - & - & 1 & - & - & - & 1 \\
\hline ST 3 & - & - & - & - & 1 & - & - & - & 1 \\
\hline ST 4 & - & - & - & - & 1 & - & - & - & 1 \\
\hline ST 5 & 1 & - & - & - & - & - & - & - & 1 \\
\hline ST 9 & 17 & 1 & - & - & - & - & - & - & 18 \\
\hline ST 10 & 7 & 2 & - & - & - & - & - & - & 9 \\
\hline ST 11 & 2 & 1 & - & - & - & - & - & - & 3 \\
\hline ST 12 & 3 & - & - & - & - & - & - & - & 3 \\
\hline ST 13 & 11 & 3 & - & - & - & - & - & - & 14 \\
\hline ST 14 & 7 & 4 & - & - & 3 & - & - & - & 13 \\
\hline ST 15 & 9 & 6 & - & - & 1 & - & - & - & 16 \\
\hline ST 16 & 7 & 5 & - & - & 3 & - & - & - & 15 \\
\hline ST 17 & 9 & 3 & - & 1 & 1 & - & - & - & 14 \\
\hline ST 18 & 4 & 1 & - & - & - & - & - & - & 5 \\
\hline ST 19 & 11 & 5 & - & - & - & - & - & - & 16 \\
\hline ST 20 & 18 & 2 & - & - & 1 & 1 & - & - & 22 \\
\hline ST 21 & 24 & 14 & - & - & 1 & - & 1 & 1 & 41 \\
\hline ST 22 & 4 & - & - & - & - & - & - & - & 4 \\
\hline ST 23 & 5 & 4 & - & - & - & - & - & - & 9 \\
\hline ST 24 & 3 & 1 & - & - & - & - & - & - & 4 \\
\hline Totals & 167 & 62 & 1 & 1 & 14 & 1 & 1 & 1 & 248 \\
\hline
\end{tabular}

$\mathrm{PS}=$ plain sherd; $\mathrm{DS}=$ decorated sherd; $\mathrm{AP}=$ arrow point; $\mathrm{LD}=$ lithic debris; $\mathrm{BC}=$ burned clay

The mean density of archaeological remains in the shovel tests is 10.1 per positive shovel test, or ca. 81 artifacts per square meter. However, the highest density of artifacts, especially ceramic vessel sherds, are in ST 20 and ST 21 south of the mound (see Figure 13). Densities of artifacts in these shovel tests range from ca. 176-328 per square meter. These shovel tests also have the only recovered burned clay, animal bone, or ceramic pipe sherds in the June 2015 investigations (see Table 2). Other shovel tests with considerable densities of artifacts and ceramic sherds in the archaeological deposits are ST 9 (ca. 144 artifacts per square meter), just north of the mound, and ST 13-17 (ca. 104-128 artifacts per square meter) northeast, east, and 
southeast of the mound at the M. S. Roberts site (see Figure 13). Clearly there are habitation deposits in the near vicinity of the constructed mound at the site, and were more shovel tests done to the east and south of the mound, these habitation deposits likely extend some distance in those directions from the mound.

The archaeological deposits in habitation areas at the M. S. Roberts site are at least $60 \mathrm{~cm}$ in thickness, based on the shovel testing (Table 3). The highest densities of artifacts occur from $20-40 \mathrm{~cm}$ bs (43 percent of the recovered artifacts), in deposits primarily below the plow zone; these deposits represent an intact and shallowly buried habitation zone, as may much of the $40-60 \mathrm{~cm}$ zone (21 percent of the recovered artifacts). Artifacts in the plow zone comprise 36 percent of the recovered artifacts in the shovel testing at the site.

Table 3. Depth of recovered artifacts in the June 2015 shovel tests at the M. S. Roberts site.

\begin{tabular}{|c|c|c|c|c|c|c|c|c|}
\hline Depth & PS & DS & LD & Tool & Bone & $\mathrm{BC}$ & $\begin{array}{l}\text { Pipe } \\
\text { Sherd }\end{array}$ & $\mathrm{N}$ \\
\hline $0-20 \mathrm{~cm}$ & 50 & 18 & 6 & 1 & 1 & - & - & 76 \\
\hline $20-40 \mathrm{~cm}$ & 60 & 24 & 4 & - & - & 1 & 1 & 90 \\
\hline $40-60 \mathrm{~cm}$ & 32 & 10 & 3 & - & - & - & - & 45 \\
\hline Totals & 142 & 52 & 13 & 1 & 1 & 1 & 1 & 211 \\
\hline
\end{tabular}

$\mathrm{PS}=$ plain sherd; $\mathrm{DS}=$ decorated sherd; $\mathrm{LD}=$ lithic debris; $\mathrm{BC}=$ burned clay

\section{Ceramic Vessel Sherds}

There are plain ware, utility ware, and fine ware ceramic vessel sherds in the June 2015 ceramic sherd assemblage (Table 4). The frequency of plain rim sherds in the assemblage (42 percent of the recovered rims) indicates that plain ware vessels are well represented. The utility ware sherds comprise 20.0 percent of the recovered sherds, and fine ware sherds account for only 7.0 percent of the recovered sherds; however 33 percent of the recovered rim sherds are from fine ware vessels.

Table 4. Ceramic sherds from the June 2015 M. S. Roberts site investigations.

\begin{tabular}{lllll}
\hline Ware & Rim & Body & Base & N \\
\hline Plain & 5 & 151 & 11 & 167 \\
Utility & 3 & 43 & - & 46 \\
Fine & 4 & 12 & - & 16 \\
\hline Totals & 12 & 206 & 11 & 229 \\
\hline
\end{tabular}

Approximately 84 percent of the ceramic sherds are from grog-tempered vessels (Table 5). Another 11.4 percent of the sherds are from vessels tempered with both grog and bone, while 5.2 percent of the sherds are from bone-tempered vessels.

Table 5. Temper use in ceramic sherds from June 2015 investigations at the M. S. Roberts site.

\begin{tabular}{lllll}
\hline Ware & Grog & Grog-Bone & Bone & N \\
\hline Plain & 138 & 22 & 7 & 167 \\
Utility & 37 & 4 & 5 & 46 \\
Fine & 16 & - & - & 16 \\
\hline Totals & 191 & 26 & 12 & 229 \\
\hline
\end{tabular}


The highest proportion of grog-tempered sherds are in the fine wares (100 percent), compared to 80.4 percent of the utility ware sherds and 82.6 percent of the plain ware sherds. The grog-bone and bone-tempered sherds occur only in the plain ware (17.4 percent of the sherds have bone temper inclusions) and utility ware (19.6 percent) (see Table 5).

The 62 decorated sherds identified in the 2015 investigations at the M. S. Roberts site include sherds with a variety of decorative methods and elements (Table 6). Utility ware sherds account for 74 percent of the decorated sherds in the assemblage.

Table 6. Decorative methods and elements in utility ware and fine ware sherds from the June 2015 investigations at the M. S. Roberts site.

\begin{tabular}{|c|c|c|}
\hline Method & Decorative element & $\mathrm{N}$ \\
\hline \multicolumn{3}{|l|}{ Utility Ware } \\
\hline \multirow[t]{2}{*}{ Appliqued } & horizontal appliqued ridges & 1 \\
\hline & straight appliqued ridge & 1 \\
\hline Brushed & parallel brushing marks & 10 \\
\hline \multirow[t]{2}{*}{ Brushed-Incised } & parallel brushed-incised marks and lines & 3 \\
\hline & $\begin{array}{l}\text { parallel brushing and overlying parallel } \\
\text { incised lines }\end{array}$ & 1 \\
\hline \multirow[t]{5}{*}{ Incised } & diagonal incised lines & 2 \\
\hline & diagonal opposed incised lines & 1 \\
\hline & opposed incised lines & 1 \\
\hline & parallel incised lines & 9 \\
\hline & straight incised line & 4 \\
\hline \multirow[t]{2}{*}{ Incised-Punctated } & $\begin{array}{l}\text { parallel incised lines and semi-circular } \\
\text { incised zone filled with linear tool } \\
\text { punctations }\end{array}$ & 1 \\
\hline & $\begin{array}{l}\text { straight incised line and adjacent linear } \\
\text { tool punctated rows }\end{array}$ & 2 \\
\hline \multirow[t]{6}{*}{ Punctated } & circular punctated rows & 1 \\
\hline & fingernail punctated rows & 1 \\
\hline & single fingernail punctate & 2 \\
\hline & linear tool punctated row & 2 \\
\hline & tool punctated row/rows & 2 \\
\hline & single tool punctate & 2 \\
\hline Subtotal, Utility Ware & & 46 \\
\hline \multicolumn{3}{|l|}{ Fine Ware } \\
\hline \multirow[t]{5}{*}{ Engraved } & curvilinear engraved line & 1 \\
\hline & curvilinear hatched area & 1 \\
\hline & curvilinear and diagonal lines & 1 \\
\hline & diagonal opposed lines & 1 \\
\hline & diagonal and horizontal lines & 2 \\
\hline
\end{tabular}


Table 6. Decorative methods and elements in utility ware and fine ware sherds from the June 2015 investigations at the M. S. Roberts site, cont.

\begin{tabular}{lll}
\hline Method & Decorative element & $\mathrm{N}$ \\
\hline \multirow{2}{*}{ Slipped } & $\begin{array}{l}\text { horizontal engraved lip below lip } \\
\text { horizontal line and hatched triangle el. } \\
\text { parallel engraved lines }\end{array}$ & 3 \\
& $\begin{array}{l}\text { exterior brown slip } \\
\text { int./ext. red slip }\end{array}$ & 2 \\
Subtotal, Fine Ware & & 1 \\
\hline Totals & & 3 \\
\hline
\end{tabular}

One of the appliqued sherds in the assemblage is a rim and strap handle sherd with horizontal appliqued ridges on the handle (Figure 15a). There are also rounded protuberances on the flat lip of the jar. The brushed and brushed-incised sherds (about 30 percent of the utility ware sherds) in the collection are from Bullard Brushed jars, while the incised and incised-punctated sherds are likely from Maydelle Incised jars. One distinctive incised-punctated has parallel incised lines as well as an incised semi-circle element filled with linear tool punctations (Figure 15c). These sherds represent 43 percent of the utility wares. The punctated sherds ( 22 percent of the utility wares) include circular ( $n=1$, Figure $15 b)$, fingernail $(n=3)$, and tool punctated $(n=6)$ decorative elements.

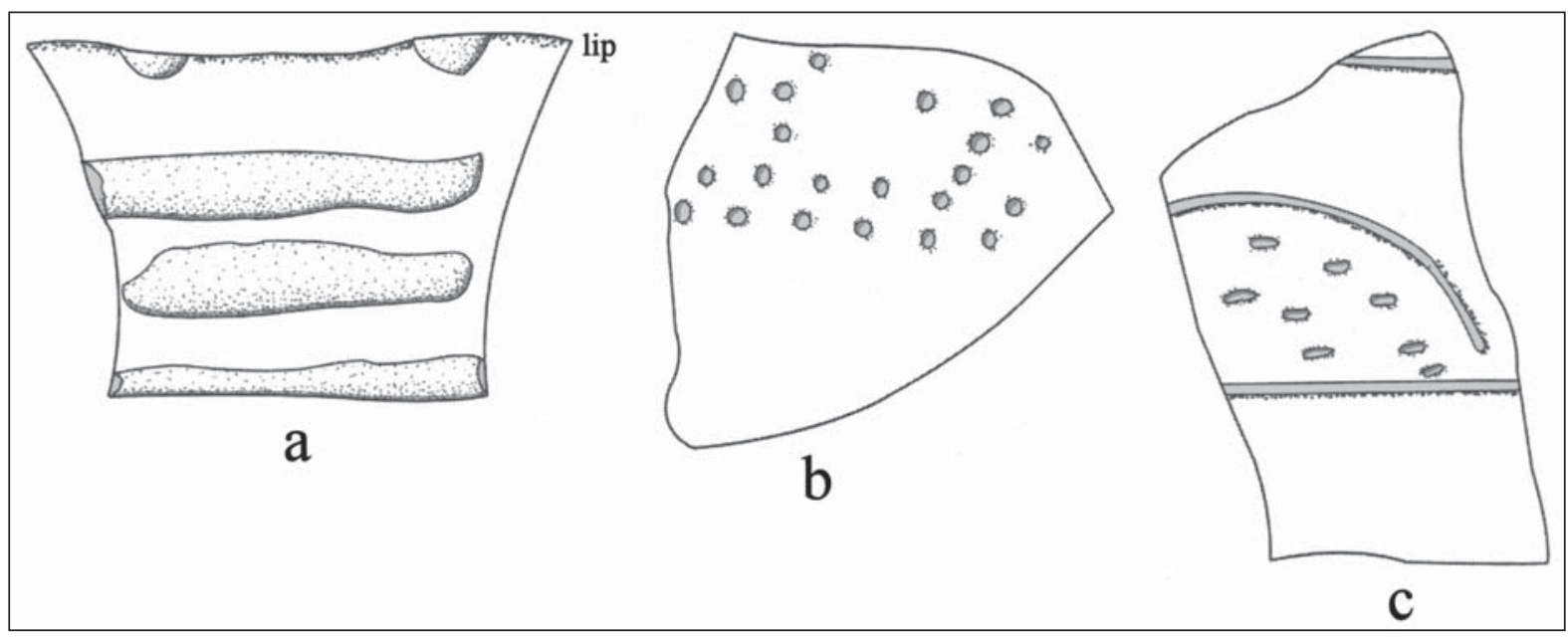

Figure 15. Selected decorative elements on utility ware sherds from the M. S. Roberts site: a, appliqued strap handle (ST 21, $40 \mathrm{~cm} \mathrm{bs);} \mathrm{b,} \mathrm{circular} \mathrm{punctated} \mathrm{body} \mathrm{sherd} \mathrm{(ST} \mathrm{14,} \mathrm{0-20} \mathrm{cm} \mathrm{bs);} \mathrm{c,} \mathrm{incised-punctated}$ body sherd (Surface collection).

The fine wares include sherds from both engraved ( 75 percent of the fine wares) and slipped ( 25 percent) vessels, including sherds from bowls, carinated bowls, and bottles. Several of the sherds are from Poynor Engraved vessels (Figure 16a, e-f), possibly var. Cook, var. Lang, or var. Blackburn (see Perttula 2011:Figure 6-64). The other engraved sherds have various combinations of curvilinear, diagonal, and horizontal engraved lines (Figure 16b-d; see also Table 5).

The slipped sherds have either a brown slip (on the exterior surface) or a red slip (on both interior and exterior vessel surfaces) (see Table 6). 


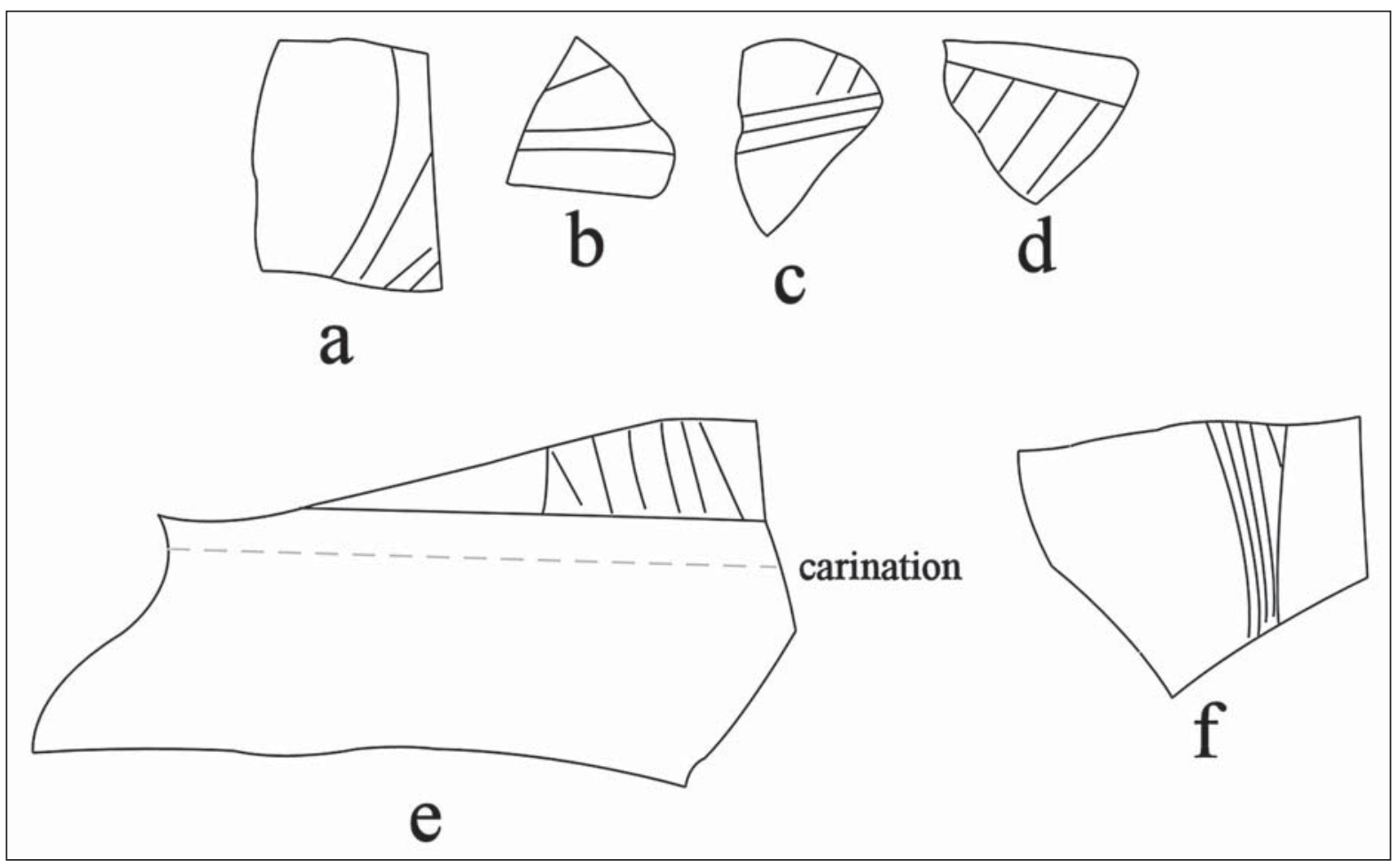

Figure 16. Selected decorative elements on fine ware sherds from the M. S. Roberts site: a, curvilinear and diagonal engraved lines (ST 19, 40-60 cm bs), Poynor Engraved; b, diagonal and horizontal engraved lines (ST 19, 20-40 cm bs); c, diagonal and horizontal engraved lines (ST 21, 20-40 cm bs); d, diagonal opposed engraved lines (ST 17, 0-20 cm bs); e, horizontal engraved line and hatched triangle element (ST 15, 40-60 cm bs), Poynor Engraved; f, curvilinear hatched area (Surface collection), Poynor Engraved).

Table 7 presents a summary of the ceramic sherd assemblage from the known collections obtained from the site in 1931 by UT archaeologists and in two different rounds of work completed in 2015. The assemblage overall is primarily composed of grog-tempered plain, utility, and fine ware vessels, as 90.5 percent of the sherds are from vessels that have had grog temper added in their paste. Nevertheless, the use of bone temper, either as the sole temper or in combination with grog, in the manufacture of vessels used, broken, and discarded at the M. S. Roberts site is substantial: 14.1 percent of the sherds.

Table 7. Summary of the ceramic sherd assemblage from the M. S. Roberts site.

Temper/

Decorative Method

Grog temper

Grog-bone temper

Bone temper
$\mathrm{N}$

453

24

50

527

for temper
$\%$

85.9

4.6

9.5

100.0

Utility Ware

Appliqued

5

1.9

Brushed

44

16.3

Brushed-Incised 
Table 7. Summary of the ceramic sherd assemblage from the M. S. Roberts site, cont.

\begin{tabular}{lll}
\hline Temper/ & $\mathrm{N}$ & $\%$ \\
Decorative Method & & \\
\hline Brushed-Punctated & 1 & 0.4 \\
Incised & 80 & 29.6 \\
Incised-Punctated & 13 & 4.8 \\
Punctated & 59 & 21.9
\end{tabular}

Fine Ware

\begin{tabular}{cll} 
Engraved & 44 & 16.3 \\
Slipped & 12 & 4.4 \\
\hline Totals, Decorated sherds & 270 & 100.0 \\
\hline
\end{tabular}

Source: Perttula 2016; Perttula and Walters 2016; this article

Over 79 percent of the decorated sherds in the M. S. Roberts site ceramic assemblages are from utility ware vessels (see Table 7). Most of these have incised, punctated, or brushed decorative elements, including sherds likely to be from Maydelle Incised $(n=93)$ and Bullard Brushed $(n=57)$ vessels. The punctated rim and body sherds cannot currently be assigned to a defined East Texas Caddo ceramic type.

Recent analyses of the character of ancestral Caddo ceramic sherd assemblages in the upper Neches River basin in East Texas have indicated several temporal changes in the proportion of brushed sherds in decorated sherd assemblages; the percentage of other wet paste decorations (i.e., incised, incised-punctated, punctated, etc.) on sherds; changes in the ratio of plain to decorated sherds (P/DR); and the ratio of brushed sherds to other wet paste decorated sherds (Table 8). These analyses have led to the recognition of six temporal sequent groups of assemblages, dating from as early as ca. A.D. 1000-1200 in the Early Caddo period (Group VI) to Historic Caddo ceramic assemblages (Group I) that date after ca. A.D. 1680.

Table 8. Comparative sherd assemblage data from Lake Palestine Caddo sites, nearby Caddo sites, and the M. S. Roberts site in the upper Neches River basin.

\begin{tabular}{|c|c|c|c|c|c|c|}
\hline Site & $\begin{array}{l}\text { No. of Dec. } \\
\text { Sherds }\end{array}$ & $\begin{array}{l}\text { \%Brushed } \\
\text { temper }\end{array}$ & $\begin{array}{l}\text { \%bone- \% } \\
\text { decorations }\end{array}$ & Wet-paste & $\mathbf{P} / \mathbf{D R}$ & $\begin{array}{l}\text { Brushed/Wet } \\
\text { paste ratio }\end{array}$ \\
\hline \multicolumn{7}{|c|}{ YOUNGEST SITES: GROUP I, Allen phase, ca. post-A.D. 1680} \\
\hline 41CE421* & 1805 & 88.1 & 5.4 & 7.8 & 0.28 & 8.5 \\
\hline $41 \mathrm{CE} 429 *$ & 465 & 87.7 & 0.8 & 9.7 & 0.22 & 9.07 \\
\hline Pine Snake* & 305 & 85.2 & 5.7 & 8.8 & 0.51 & 9.63 \\
\hline 41CE354* & 474 & 82.7 & 3.1 & 8.9 & 0.20 & 8.14 \\
\hline \multicolumn{7}{|c|}{ GROUP II, latest Frankston phase, ca. A.D. 1560-1680 } \\
\hline 41CE324 & 188 & 81.9 & 3.2 & 7.3 & 0.48 & 11.0 \\
\hline Debro & 311 & 80.0 & $?$ & 10.3 & 0.14 & 7.75 \\
\hline $\begin{array}{l}\text { William } \\
\text { Sherman }\end{array}$ & 525 & 75.8 & $?$ & 16.2 & 0.44 & 4.68 \\
\hline \multicolumn{7}{|c|}{ GROUP III, Frankston phase, ca. A.D. 1480-1560 } \\
\hline Forest Drive & 1693 & 68.6 & $?$ & 21.9 & 0.56 & 3.12 \\
\hline Halbert & 1757 & 65.8 & 2.6 & 26.3 & 0.70 & 2.51 \\
\hline Woldert & 1730 & 62.7 & 0.0 & 28.8 & 0.72 & 2.19 \\
\hline Ferguson & 4116 & 60.8 & $<1.0$ & 27.9 & 0.61 & 2.17 \\
\hline
\end{tabular}


Table 8. Comparative sherd assemblage data from Lake Palestine Caddo sites, nearby Caddo sites, and the M. S. Roberts site in the upper Neches River basin, cont.

\begin{tabular}{|c|c|c|c|c|c|c|}
\hline Site & $\begin{array}{l}\text { No. of Dec. } \\
\text { Sherds }\end{array}$ & $\begin{array}{l}\text { \%Brushed } \\
\text { temper }\end{array}$ & $\begin{array}{l}\text { \%bone- \% } \\
\text { decorations }\end{array}$ & Wet-paste & $\mathbf{P} / \mathbf{D R}$ & $\begin{array}{l}\text { Brushed/Wet } \\
\text { paste ratio }\end{array}$ \\
\hline \multicolumn{7}{|c|}{ GROUP IV, earliest Frankston phase, ca. A.D. 1400-1480 } \\
\hline Tomato Patch & 912 & 49.2 & $?$ & 41.7 & 1.50 & 1.21 \\
\hline Lang Pasture & 2435 & 35.9 & 6.7 & 38.0 & 1.40 & 0.91 \\
\hline Mitchell, D & 54 & 32.1 & 0.0 & 33.3 & 1.37 & 1.50 \\
\hline M. S. Roberts & 270 & 21.1 & 14.1 & 63.0 & 1.90 & 0.34 \\
\hline \multicolumn{7}{|c|}{ GROUP V, Middle Caddo period, ca. A.D. 1200-1400 } \\
\hline 41SM404 & 446 & 16.0 & 8.5 & 60.7 & 1.73 & 0.26 \\
\hline White Mule & 1404 & 18.5 & 1.5 & 63.7 & 2.61 & 0.29 \\
\hline 41HE139 & 40 & 17.5 & 8.1 & 65.0 & 2.51 & 0.33 \\
\hline \multicolumn{7}{|c|}{ OLDEST SITE: GROUP VI, Early Caddo period, ca. A.D. 1000-1200 } \\
\hline Mitchell, A-C & 56 & 1.3 & 12.0 & 65.7 & 1.71 & 0.03 \\
\hline
\end{tabular}

$\mathrm{P} / \mathrm{DR}=$ plain to decorated sherd ratio

* sites with Patton Engraved sherds

?=information not provided in Anderson et al. (1974)

Using these sherd assemblage metrics to assess the temporal placement of the Caddo occupation at the M. S. Roberts site indicates that the occupation may well date to the latter part of the Middle Caddo period, given the proportion of brushed sherds and the proportion of other decorated wet paste sherds, or in Group IV, the earliest part of the Frankston phase (see Table 8), as had been previously suggested. Poynor Engraved, represented by several sherds in the assemblage, is primarily a Frankston phase (ca. A.D. 1400-1680) type, developing in a stylistic tradition that extends back some amount of time before A.D. 1400 (perhaps as early as ca. A.D. 1320 at several sites in the upper Neches River basin), and is also found on Caddo sites in the upper Neches that date after ca. A.D. 1680 (Perttula 2011:281). Given these archaeological findings and the overall character of the sherd metrics summarized in Table 8, we suggest that the Caddo occupation of the M. S. Roberts site may well have begun in the $14^{\text {th }}$ century, perhaps sometime after ca. A.D. 1300, and ended sometime in the early Frankston phase (Group IV). Clearly, a well-controlled series of calibrated radiocarbon dates are needed from both mound and habitation contexts at the site to definitively establish its age, and thus its relationship to other mound and non-mound sites along Caddo Creek and in the upper Neches River basin.

\section{Ceramic Pipe Sherd}

A single ceramic pipe sherd was recovered in the June 2015 work at the M. S. Roberts site. This was a plain grog-tempered elbow pipe bowl sherd from ST 21, 20-40 cm bs. A Var. B elbow pipe fragment found by a local collector may have come from the site (Figure 17). This elbow pipe form has a flaring bowl and a distal stem knob, with three horizontal engraved lines on the stem and lower bowl (Perttula 2011:215 and Figure 6-23). Such pipes have been found in ca. A.D. 1400-1560 contexts at a number of upper Neches River basin sites.

\section{Burned Clay Pieces}

One piece of burned clay was found between $20-40 \mathrm{~cm}$ bs in ST 21. It likely represents the remnants of cooking/heating activities associated with the use of an earth oven or cooking pit by the Caddo group living at the site. 


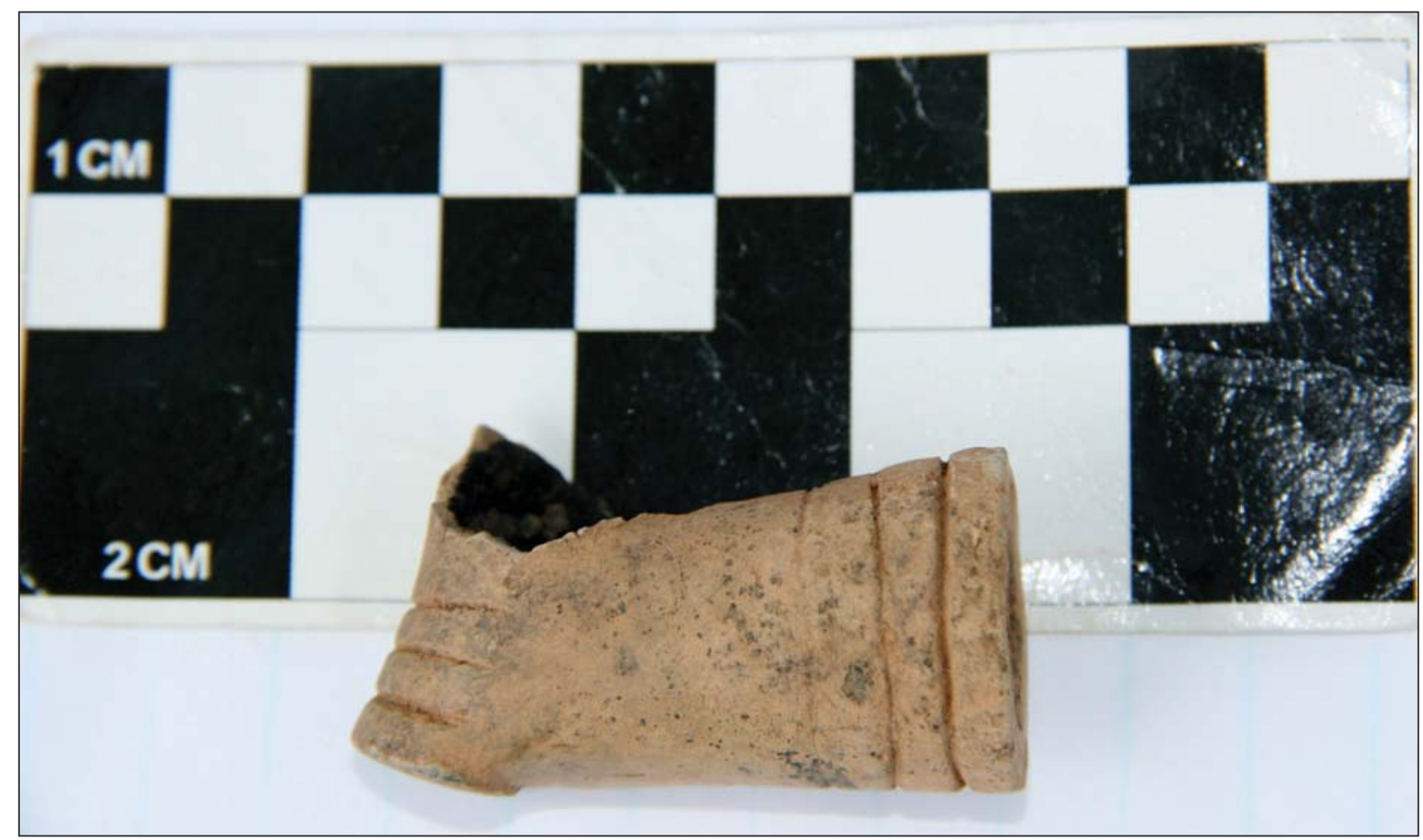

Figure 17. Var. B elbow pipe fragment reportedly from the M. S. Roberts site.

\section{Lithic Artifacts}

Chipped stone lithic artifacts are uncommon in the recovered artifacts from the June 2015 investigations at the M. S. Roberts site. They include a bifacially flaked dark brown chert arrow point blade midsection from the surface of the site - the blade is serrated, $14.5 \mathrm{~mm}$ in maximum width, and $2.4 \mathrm{~mm}$ thick - and a possible unifacial gouge fragment from ST $17(0-20 \mathrm{~cm}$ bs) (Table 9). The possible tool fragment has flake removals at one end of the piece, and is made on a local ferruginous sandstone.

Table 9. Lithic artifacts recovered in the June 2015 archaeological investigations at the M. S. Roberts site.

\begin{tabular}{llll}
\hline Provenience & Tool & Lithic Debris & $\mathrm{N}$ \\
\hline Surface & $\begin{array}{l}1 \text { arrow point } \\
\text { blade frag }\end{array}$ & - & 1 \\
ST B-4, $40-60 \mathrm{~cm}$ & - & 1-dark gray chert & 1 \\
ST $1,20-40 \mathrm{~cm}$ & - & 1-gray chert & 1 \\
ST 3, $0-20 \mathrm{~cm}$ & - & 1-brown chert & 1 \\
ST $4,0-20 \mathrm{~cm}$ & - & 1-grayish-brown & 1 \\
ST $14,0-20 \mathrm{~cm}$ & - & chert & \\
ST $15,0-20 \mathrm{~cm}$ & - & 3-gray chert & 3
\end{tabular}


Table 9. Lithic artifacts recovered in the June 2015 archaeological investigations at the M. S. Roberts site, cont.

\begin{tabular}{llll}
\hline Provenience & Tool & Lithic Debris & N \\
\hline ST 16, 20-40 cm & - & 1-gray chert & 1 \\
ST 16, $40-60 \mathrm{~cm}$ & - & 2 -gray chert & 2 \\
ST 17, 0-20 cm & $\begin{array}{l}1 \text { possible gouge } \\
\text { fragment }\end{array}$ & - & 1 \\
ST 20, 20-40 cm & - & $\begin{array}{l}\text { 1-ferruginous } \\
\text { sandstone }\end{array}$ & 1 \\
ST 21, 0-20 cm & & 1-reddish-brown & 1 \\
\hline Totals & - & chert & 16 \\
\hline
\end{tabular}

A total of 14 pieces of lithic debris were recovered in 10 shovel tests, a mean density of 1.4 pieces per shovel test, or ca. 11.2 pieces of lithic debris per square meter. The highest densities (ca. 24 pieces per square meter) are in ST 14 and ST 16 to the east of the mound at the M. S. Roberts site (see Figure 13).

The majority of lithic debris is from gravel raw material sources in either the Neches or Trinity rivers. One piece of lithic debris in ST $16(20-40 \mathrm{~cm}$ bs) has limestone cortex, suggesting it may have been flaked from a piece of gray chert from a Central Texas source. The lithic debris includes various colors of chert (86 percent), as well as petrified wood (7 percent), and ferruginous sandstone (7 percent).

\section{Animal Bones}

There was one piece of burned animal bone recovered during the June 2015 work at the M. S. Roberts site. It was found in ST 20 between $0-20 \mathrm{~cm}$ bs.

\section{Summary and Conclusions}

The M. S. Roberts site (41HE8) is an ancestral Caddo mound center and habitation site near Caddo Creek in the upper Neches River basin in June 2015. The site was first investigated by The University of Texas in 1931, and then forgotten by the archaeological community. The site was relocated in January 2015, thanks to access graciously provided by the landowners (who had known about the site for years), and the site appeared to be essentially intact and well-preserved. In June 2015, we initiated further archaeological study of the M. S. Roberts site, beginning with an aerial flyover using a drone to develop a detailed topographic map of the site as well as topographic profiles across the landform, along with shovel testing in mound and non-mound contexts, and the excavation of auger holes in the mound and a likely nearby borrow pit area. The shovel tests excavations were primarily designed to locate associated non-mound ancestral Caddo habitation deposits, while the auger holes were excavated to investigate the internal structure of the one known mound on the M. S. Roberts site.

The aerial survey delineated the mound and borrow pit features through examining the DEM and a $10 \mathrm{~cm}$ contour interval. The mound was visible as a slightly oblong feature extending from the baseline elevation to a maximum height of $91 \mathrm{~cm}$, with an aerial extent of $855 \mathrm{~m}^{2}$. The edges of the borrow pit show as a clear isolated depression visible extending from $56 \mathrm{~cm}$ below the baseline elevation to a maximum depth of 87 $\mathrm{cm}$. The aerial extent of the borrow pit is mapped as encompassing $2000 \mathrm{~m}^{2}$, although it is likely that the maximum extent of borrowing is larger. Based on these extents, the mound and borrow pit volumes were 
calculated relative to the baseline elevation, with the volume of the mound being 313.68 cubic meters, while the total volume represented by the known borrow pit area is 270.82 cubic meters, or 86 percent of the total estimated mound volume.

Shovel tests on the western side of the landform contained only a low density of prehistoric lithic debris of an unknown age. Shovel tests on the eastern side of the landform contain archaeological deposits from 0-60 $\mathrm{cm}$ bs with a considerable density of ancestral Caddo sherds. These shovel tests covered a ca. $100 \mathrm{x} 50$ $\mathrm{m}$ area (ca. 1.2 acres, but the overall extent of the archaeological deposit at the site has not been established through the shovel testing effort; the habitation deposits likely extend to the east onto an adjoining property. These positive shovel tests indicate that there are habitation deposits in the near vicinity of the constructed mound at the site. The archaeological deposits in habitation areas at the M. S. Roberts site are at least $60 \mathrm{~cm}$ in thickness. The highest densities of artifacts occur from $20-40 \mathrm{~cm}$ bs, in deposits primarily below the plow zone; these deposits represent an intact and shallowly buried habitation zone, as may much of the 40-60 cm bs zone.

Auger holes were excavated in the mound as well as in a likely low borrow pit area about $20 \mathrm{~m}$ west of the northern part of the mound at the M. S. Roberts site. The profiles in the mound have a variety of mound fill zones, including sandy loams, clay loams, and a mixture of sandy loam and red and gray clay chunks. Two auger holes encountered a very dark sandy loam zone between $102-135 \mathrm{~cm}$ bs and $120-140 \mathrm{~cm}$ bs that may represent the remains of a burned structure encountered during the 1931 UT work. No clay floor was encountered in any of the auger holes, but significant amounts of gray clay chunks were noted between 83$119 \mathrm{~cm}$ bs in one of the auger holes. The base of the mound may lie at ca. $140 \mathrm{~cm}$ bs, with underlying dark yellowish-brown or yellowish-brown sandy loam or sand deposits representing the buried A- and E-horizons on the landform.

A total of 248 artifacts have been recovered in the June 2015 archaeological investigations at the M. S. Roberts site, including a general site surface collection. Twenty-one shovel tests contain archaeological remains, including plain and decorated sherds, one chipped stone tool fragment, lithic debris, one animal bone, burned clay, and one ceramic pipe sherd. More than 90 percent of the recovered artifacts are plain and decorated sherds from plain, utility, and fine ware vessels. The ceramic sherd assemblage is primarily composed of grog-tempered vessels, as 90.5 percent of the sherds are from vessels that have had grog temper added in their paste. The use of bone temper, either as the sole temper or in combination with grog, in the manufacture of vessels comprises 14.1 percent of the sherds.

Combining the various sherd assemblages obtained from the M. S. Roberts site, including the June 2015 work (see Perttula 2016; Perttula and Walters 2016), especially the kind and proportion of decorated sherds, suggests that the occupation of the site by Caddo peoples may date to the latter part of the Middle Caddo period or the earliest part of the Late Caddo period Frankston phase, beginning in the $14^{\text {th }}$ century, perhaps sometime after ca. A.D. 1300, and ended sometime in the early Frankston phase, by ca. A.D. 1480. We hope that future work at the site can obtain a well-controlled series of calibrated radiocarbon dates from both mound and habitation contexts at the M. S. Roberts site to establish its age as well as its relationship to other mound and non-mound sites along Caddo Creek and in the upper Neches River basin.

\section{Acknowledgments}

We thank Jim and Denise Renfroe for their permission to conduct investigations at the M. S. Roberts site in June 2015. We also very much appreciate their efforts to protect and preserve the site. Lance Trask and Sandy Hannum prepared various figures in this article, as did Arlo McKee. 


\section{References Cited}

Anderson, K. M., K. Gilmore, O. F. McCormick III, and E. P. Morenon

1974 Archaeological Investigations at Lake Palestine, Texas. Contributions in Anthropology No. 11. Department of Anthropology, Southern Methodist University, Dallas.

Colomina, I. and P. Molina

2014 Unmanned aerial systems for photogrammetry and remote sensing: A review. ISPRS Journal of Photogrammetry and Remote Sensing 92:79-97.

Gonçalves, J. A. and R. Henriques

2015 UAV photogrammetry for topographic monitoring of coastal areas. ISPRS Journal of Photogrammetry and Remote Sensing 104:101-111.

Hesse, R.

2015 Combining Structure-from-Motion with high and intermediate resolution satellite images to document threats to archaeological heritage in arid environments. Journal of Cultural Heritage 16(2):192-201.

Lerma, J. L. and C. Muir

2014 Evaluating the 3D documentation of an early Christian upright stone with carvings from Scotland with multiples images. Journal of Archaeological Science 46:311-318.

Lowe, D. G

2004 Distinctive Image Features from Scale-Invariant Keypoints. International Journal of Computer Vision 60(2):91-110.

Martínez, S., J. Ortiz, and M. L. Gil

2015 Geometric documentation of historical pavements using automated digital photogrammetry and high-density reconstruction algorithms. Journal of Archaeological Science 53:1-11.

Pearce, J. E. and A. T. Jackson

1931 M. S. Roberts Farm, Henderson County, Texas Oct. 8 to Oct. 11, 1931. MS on file, Texas Archeological Research Laboratory, The University of Texas at Austin.

Perttula, T. K.

2011 The Ceramic Artifacts from the Lang Pasture Site (41AN38) and the Place of the Site within an Upper Neches River Basin Caddo Ceramic Tradition. In Archeological Investigations at the Lang Pasture Site (41AN38) in the Upper Neches River Basin of East Texas, assembled and edited by T. K. Perttula, D. B. Kelley, and R. A. Ricklis, pp. 145-320. Archeological Studies Program Report No. 129, Texas Department of Transportation, Environmental Affairs Division, Austin.

Perttula, T. K., with contributions by W. Troell

2016 The A. S. Mann (41HE7/41AN201) and M. S. Roberts (41HE8) Sites in the Upper Neches River Basin, Henderson County, Texas. Journal of Northeast Texas Archaeology 59:1-9.

Perttula, T. K. and M. Walters

2016 Recent Artifact Surface Collections from the M. S. Roberts (41HE8) Mound Site in the Upper Neches River Basin in East Texas. Journal of Northeast Texas Archaeology 59:69-74.

Perttula, T. K., M. Walters, and B. Nelson

2012 Archeological Investigations at the Pace McDonald Site (41AN51): A Middle Caddo Mound Center in the Neches River Basin in East Texas. Special Publication No. 21. Friends of Northeast Texas Archaeology, Pittsburg and Austin.

Sanger, M. C.

2015 Determining depositional events within shell deposits using computer vision and photogrammetry. Journal of Archaeological Science 53:482-491. 
Suhm, D. A. and E. B. Jelks (editors)

1962 Handbook of Texas Archeology: Type Descriptions. Special Publication No. 1, Texas Archeological Society, and Bulletin No. 4, Texas Memorial Museum, Austin. Reprinted in 2009, Gustav's Library, Davenport, Iowa.

Tonkin, T. N., N. G. Midgley, D. J. Graham, and J. C. Labadz

2014 The potential of small unmanned aircraft systems and structure-from-motion for topographic surveys: A test of emerging integrated approaches at Cwm Idwal, North Wales. Geomorphology 226:35-43. 